\title{
Role of the Anilinium Ion on the Selective Polymerization of Anilinium 2-Acrylamide-2-methyl-1-propanesulfonate
}

\author{
Alain Salvador Conejo-Dávila ${ }^{1}$, Marco Armando Moya-Quevedo ${ }^{1} \mathbb{D}$, David Chávez-Flores ${ }^{2}$, \\ Alejandro Vega-Rios ${ }^{1, *(D)}$ and Erasto Armando Zaragoza-Contreras ${ }^{1, *}$ (D) \\ 1 Department of Engineering and Materials Chemistry, Centro de Investigación en Materiales Avanzados, \\ S.C., Miguel de Cervantes No. 120, Complejo Industrial Chihuahua, Chihuahua C.P. 31136, Mexico; \\ alain.conejo@cimav.edu.mx (A.S.C.-D.); armando_10ncg@hotmail.com (M.A.M.-Q.) \\ 2 Facultad de Ciencias Químicas, Universidad Autónoma de Chihuahua, Chihuahua C.P. 31125, Mexico; \\ dchavezf@uach.mx \\ * Correspondence: alejandro.vega@cimav.edu.mx (A.V.-R.); armando.zaragoza@cimav.edu.mx (E.A.Z.-C.)
}

Citation: Conejo-Dávila, A.S.; Moya-Quevedo, M.A.; Chávez-Flores, D.; Vega-Rios, A.; Zaragoza-Contreras, E.A. Role of the Anilinium Ion on the Selective Polymerization of Anilinium 2-Acrylamide-2-methyl-1propanesulfonate. Polymers 2021, 13, 2349. https://doi.org/10.3390/ polym13142349

Academic Editor:

Yaroslav O. Mezhuev

Received: 12 June 2021

Accepted: 6 July 2021

Published: 17 July 2021

Publisher's Note: MDPI stays neutral with regard to jurisdictional claims in published maps and institutional affiliations.

Copyright: (c) 2021 by the authors. Licensee MDPI, Basel, Switzerland. This article is an open access article distributed under the terms and conditions of the Creative Commons Attribution (CC BY) license (https:// creativecommons.org/licenses/by/ $4.0 /)$

\begin{abstract}
The development of anilinium 2-acrylamide-2-methyl-1-propanesulfonate (Ani-AMPS) monomer, confirmed by ${ }^{1} \mathrm{H} N M R,{ }^{13} \mathrm{C}$ NMR, and FTIR, is systematically studied. Ani-AMPS contains two polymerizable functional groups, so it was submitted to selective polymerization either by free-radical or oxidative polymerization. Therefore, poly(anilinium 2-acrylamide-2-methyl-1-propanesulfonic) [Poly(Ani-AMPS)] and polyaniline doped with 2-acrylamide-2-methyl-1-propanesulfonic acid [PAni-AMPS] can be obtained. First, the acrylamide polymer, poly(Ani-AMPS), favored the $\pi$-stacking of the anilinium group produced by the inter- and intra-molecular interactions and was studied utilizing ${ }^{1} \mathrm{H} N \mathrm{NR},{ }^{13} \mathrm{C} \mathrm{NMR}$, FTIR, and UV-Vis-NIR. Furthermore, poly(Ani-AMPS) fluorescence shows quenching in the presence of $\mathrm{Fe}^{2+}$ and $\mathrm{Fe}^{3+}$ in the emission spectrum at $347 \mathrm{~nm}$. In contrast, the typical behavior of polyaniline is observed in the cyclic voltammetry analysis for PAni-AMPS. The optical properties also show a significant change at $\mathrm{pH}$ 4.4. The PAni-AMPS structure was corroborated through FTIR, while the thermal properties and morphology were analyzed utilizing TGA, DSC (except PAni-AMPS), and FESEM.
\end{abstract}

Keywords: benzenaminium salts; free-radical polymerization; oxidative polymerization; polyaniline; selective polymerization; fluorescent polymer; $\pi$-stacking interactions

\section{Introduction}

Currently, there are two strategies for developing complex polymeric structures. The first approach is post-functionalization; however, it has the drawback that there is no way to control the degree of modification of the polymer [1,2]. The second synthesis pathway is monomeric design with a specific application [3,4]. In particular, monomers with two polymerizable sites or bifunctional monomers are the most used. If they contain polymerizable sites, they react by the exact polymerization mechanism, causing crosslinking $[5,6]$. However, when bifunctional monomers have different polymerizable groups, complex structures can be obtained. For example, Chan et al. [7] synthesized polythiophene phenylenes-g-polystyrene from a bifunctional monomer of modified thiophene phenylenes. Additionally, Klein et al. [8] reported developing a modified hydrogel through a bifunctional monomer that presents an epoxy functional group and maleimide substituents. Nevertheless, the synthesis route to develop these monomers is complicated and requires multiple steps. This study provides new insights into selective polymerization by designing a monomer of easy synthesis and polymerizable groups with different polymerization mechanisms. The use of these monomers will make it possible to build complex systems made up of two or more polymers with new properties or intrinsic characteristics of the system.

Additionally, our group recently reported the benzenaminium 4-styrenesulfonate salt. It was selectively polymerized to produce polyaniline or poly(benzenaminium 4-styrenesulfonate) [9]. This monomer has two aromatic rings that induce $\pi$-stacking 
interactions with itself [10]. The sulfonated aromatic fragment also provides hardness and stiffness to the polymer product obtained by the free-radical mechanism. It is important to note that the selective polymerization allowed the obtaining of core-shell nanoparticles, polystyrene-polyaniline, where the bifunctional monomer played the role of a bridge between both polymer phases [11].

The anilinium salts are produced by the acid-base reaction between aniline (pKa of 4.6) and a Brønsted-Lowry acid. Similarly, the Ani-AMPS monomer synthesis occurs under an identical reaction mechanism and involves versatile and easy-to-implement reactions; however, $\mathrm{pH}$ control is necessary according to the anion (conjugate base). The protonated nitrogen, also linked to the benzene ring, attracts the electronic density, allowing an alternate $\pi$-stacking conformation [12]. The benzenaminium cation affects the crystalline structure [13], solubility [14], and optical properties [15] of its salts due to the attraction forces (hydrogen bonding, van der Waals forces, coordination bonding) acting between them $[10,15]$. The physicochemical properties and the structural arrangement of the anilinium cation provide it with a variety of applications. For example, anilinium salts can be found in surfactants [16], ionic liquids [17], ionic semiconductors [18], lasers [15], organogels [19], and monomers, usually for polyaniline synthesis [20]. This variety of applications owes to the different types of the anion (organic or inorganic), typically analogous to sulfate and sulfonate, which have the function of cation anilinium stabilization.

Moreover, the oxidative polymerization of anilinium salts is a strategy to control doping in the PAni. The dopant determines the conductivity, electrochemical, and optical properties [11]. At a high concentration, the dopants do not significantly favor conductive or electroactive properties but increase the interaction of PAni with other compounds [21].

2-acrylamide-2-methyl-1-propanesulfonic acid (AMPS-acid) is an amphiphilic monomer analog of sulfonic acid, whose sodium salt is used as a flocculent and additive in paper production [22]. This compound is an aliphatic molecule that presents an amide functional group, allowing it to take different conformations and carry out hydrogen bonding depending on the solvent. The polymer derived from free-radical polymerization is poly(2-acrylamide-2-methyl propanesulfonic acid) (PAMPS-acid), a water-soluble and film-forming polymer, and is widely used as a polyelectrolyte to make hydrogels due to its high proton conductivity [23].

This paper reports the development of anilinium 2-acrylamide-2-methyl-1-propanesulfonate (Ani-AMPS). This new bifunctional monomer was submitted to selective polymerization (free-radical or oxidative polymerization), producing polymers with an altogether different structure. Particular emphasis was placed on how the anilinium group affects those properties. For example, compared with polyaniline doped with 2-acrylamide-2-methyl-1-propanesulfonic acid (PAni-AMPS), the poly(anilinium 2-acrylamide-2-methyl-1-propanesulfonic) [Poly(AniAMPS)] presented a selective turn-off fluorescent property in the presence of iron cations $\left(\mathrm{Fe}^{2+}\right.$ and $\left.\mathrm{Fe}^{3+}\right)$ in an aqueous solution, whereas PAni-AMPS exhibited a significant change when studying the optical properties based on the $\mathrm{pH}$ and typical behavior of conducting polymers.

\section{Materials and Methods}

\subsection{Materials}

Aniline (Merck, Sigma-Aldrich, St. Louis, MO, USA >99.5\%), prior to the experiment, was vacuum distilled, and ammonium persulfate (Merck, Sigma-Aldrich, St. Louis, MO, USA >98\%), 2-acrylamide-2-methylpropane-1-sulfonic acid (Merck, Sigma-Aldrich, St. Louis, MO, USA >99\%), sodium metabisulfite (Merck, Sigma-Aldrich, St. Louis, MO, USA >97\%), acetone (Merck, Sigma-Aldrich, St. Louis, MO, USA), hydrochloric acid (Fermont, Monterrey, Nuevo León, México, 37\%), ethanol (J.T. Baker, Phillipsburg, NJ, USA ), deuterium oxide (Merck, Sigma-Aldrich, St. Louis, MO, USA), methanol (J.T. Baker, Phillipsburg, NJ, USA), 1-propanol (J.T. Baker, Phillipsburg, NJ, USA), 2-propanol (J.T. Baker, Phillipsburg, NJ, USA), 1-butanol (J.T. Baker, Phillipsburg, NJ, USA ), and formic acid (Merck, Sigma-Aldrich, St. Louis, MO, USA) were used as received. 


\subsection{Synthesis of Anilinium Salt}

Figure 1a illustrates the reaction for anilinium 2-acrylamide-2-methyl-1-propanesulfonate (Ani-AMPS) monomer synthesis. In a flat-bottomed flask $(50 \mathrm{~mL})$ equipped with a stirring bar and ice bath at $5{ }^{\circ} \mathrm{C}, 10 \mathrm{~mL}$ of an aqueous solution of AMPS-acid [1.93 M] was loaded. Next, aniline (19.3 mmol) was added dropwise under continuous magnetic stirring. Afterward, the flask was removed from the ice bath, and the reaction was left for $6 \mathrm{~h}$ at $25^{\circ} \mathrm{C}$. Subsequently, the water was evaporated at room temperature, and the solid was ground with a mortar. The solid was purified with two cycles of dispersion with acetone $(25 \mathrm{~mL})$ and filtration (yield 98\%). ${ }^{1} \mathrm{H}$ NMR $(400 \mathrm{MHz}$, deuterium oxide) $\delta 7.64-7.54(\mathrm{~m}, 3 \mathrm{H}), 7.45(\mathrm{dt}, J=8.0,1.5 \mathrm{~Hz}, 2 \mathrm{H})$, $6.26(\mathrm{dd}, J=17.1,10.1 \mathrm{~Hz}, 1 \mathrm{H}), 6.16(\mathrm{dd}, J=17.1,1.5 \mathrm{~Hz}, 1 \mathrm{H}), 5.72(\mathrm{dd}, J=10.1,1.5 \mathrm{~Hz}, 1 \mathrm{H})$, $3.44(\mathrm{~s}, 2 \mathrm{H}), 1.53(\mathrm{~s}, 6 \mathrm{H}) ;{ }^{13} \mathrm{C}$ NMR (101 MHz, Deuterium oxide) $\delta 197.79$, 130.99, 130.11, 129.75, 129.20, 126.57, 122.85, 57.15, 51.98, 26.36 ppm, see Figure S1; FTIR (ATR) $\mathrm{v}_{\max } / \mathrm{cm}^{-1} 3276,2875$, $2638,1654,1620,1177,1157,1041$.

a) Monomer synthesis

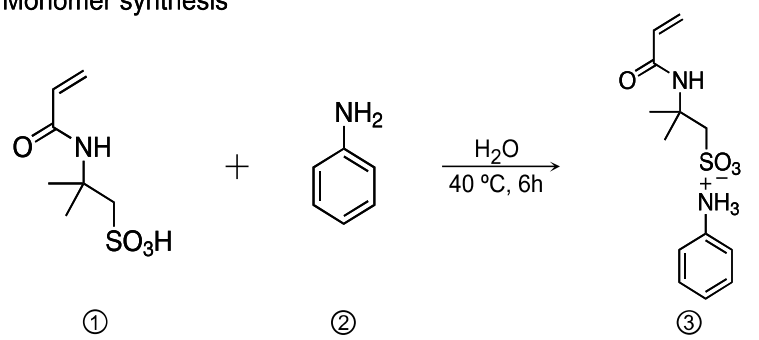

(1) 2-Acrylamide-2-methyl-1-propanesulfonic acid

(2) Aniline

(3) Anilinium 2-acrylamide-2-methyl-1-propanesulfonic

b) Free-radical polymerization
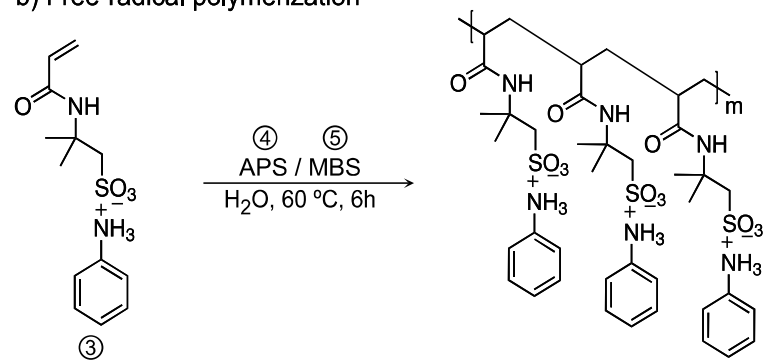

(4) Ammonium persulfate

(5) Sodium metabisulfite

(6) Poly(anilinium 2-acrylamide-2-methyl-1-propanesulfonic)

c) Oxidative polymerization

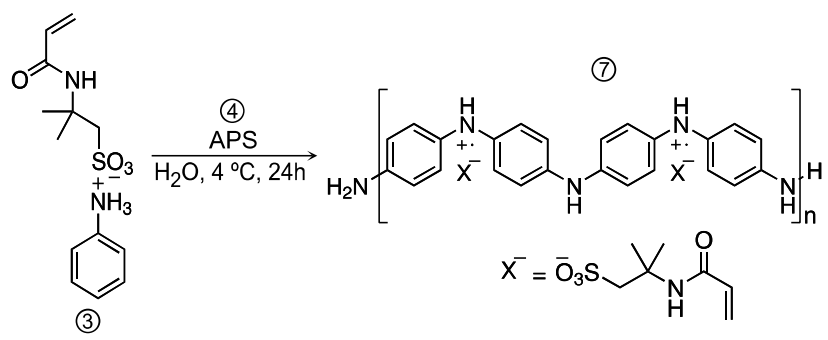

(7) Polyaniline doped with 2-acrylamide-2-methyl-1-propanesulfonic acid

Figure 1. The synthesis scheme of (a) Ani-AMPS; (b) free-radical polymerization of Ani-AMPS monomer; and (c) oxidative polymerization of Ani-AMPS monomer.

\subsection{Free-Radical Polymerization of Ani-AMPS}

The free-radical polymerization of Ani-AMPS, shown in Figure 1b, was performed in a flask equipped with a stirring bar, temperature control, and nitrogen atmosphere. Aqueous solutions of Ani-AMPS [75 $\times 10^{-3} \mathrm{M}$ ] and sodium metabisulfite $\left[3.34 \times 10^{-3} \mathrm{M}\right]$ were added together (volume total $24 \mathrm{~mL}$ ). At this point, the $\mathrm{pH}$ value was near 4 . The monomer solution and 
initiator were nitrogen bubbled for $20 \mathrm{~min}$ and heated to $60{ }^{\circ} \mathrm{C}$. At this time, $6 \mathrm{~mL}$ of an aqueous solution of ammonium persulfate $\left[6.67 \times 10^{-3} \mathrm{M}\right]$ was injected into the reactor to launch the polymerization. The polymerization was left for $6 \mathrm{~h}$ under a nitrogen atmosphere and continuous stirring. When the polymerization finished, the water was eliminated at room temperature. The poly(anilinium 2-acrylamide-2-methyl-1-propanesulfonate), poly(AniAMPS), was purified under the precipitation technique (three times), dissolved in water $(5 \mathrm{~mL})$ and acetone $(25 \mathrm{~mL})$ as non-solvent. The product was filtered, and residual acetone evaporated at room temperature (yield 95\%). Spectral data: ${ }^{1} \mathrm{H}$ NMR (400 MHz, deuterium oxide) $\delta 7.80-7.29(\mathrm{~m}, 10 \mathrm{H}), 3.71(\mathrm{t}, J=6.3 \mathrm{~Hz}, 1 \mathrm{H}), 3.49-3.25(\mathrm{~m}, 4 \mathrm{H}), 2.67(\mathrm{t}, J=6.3 \mathrm{~Hz}, 1 \mathrm{H})$, $2.10(\mathrm{~m}, 2 \mathrm{H}), 1.82-1.55(\mathrm{~m}, 2 \mathrm{H}), 1.53-1.43(\mathrm{~m}, 12 \mathrm{H}) ;{ }^{13} \mathrm{C}$ NMR $(101 \mathrm{MHz}$, Deuterium Oxide) $\delta 170.89,167.79,133.93,130.98,130.43,130.14,129.65,129.67,126.56,122.94,122.69$, 57.12, 56.59, 51.97, 51.87, 47.73, 31.30, 26.55, 26.37, 26.35 ppm; see Supplementary Figure S2; FTIR (ATR) $\mathrm{v}_{\max } / \mathrm{cm}^{-1} 3300,3072,2971,2614,1657,1552,1177$.

\subsection{Oxidative Polymerization}

Figure 1c shows the oxidative polymerization of Ani-AMPS. Firstly, an aqueous solution of the monomer $\left[12 \times 10^{-2} \mathrm{M}\right]$ was prepared. In another graduated vessel, the ammonium persulfate $\left[15 \times 10^{-2} \mathrm{M}\right]$ solution was formulated. Both solutions (total volume $50 \mathrm{~mL}$ ) were poured into a $250 \mathrm{~mL}$ vessel and mixed thoroughly for $5 \mathrm{~min}$. The polymerization was left for $24 \mathrm{~h}$, at $4{ }^{\circ} \mathrm{C}$. Afterward, the byproducts of the polymerization were removed with cycles (three times) of centrifugation (5000 rpm for $10 \mathrm{~min}$ ) and washing with an $\mathrm{HCl}$-ethanol solution ( $5 \mathrm{vol} \%$ ). The polymer product was recovered by evaporation at room temperature (yield 95\%). FTIR (ATR) $\mathrm{v}_{\max } / \mathrm{cm}^{-1} 3204,2838,1655,1584,1563,1488$, 1296, 810.

\subsection{Characterization}

The characterization by proton nuclear magnetic resonance $\left({ }^{1} \mathrm{H}\right.$ NMR) and carbon nuclear magnetic resonance $\left({ }^{13} \mathrm{C}\right.$ NMR) of Ani-AMPS and Poly(Ani-AMPS) was performed using a Brucker spectrometer (NMR Bruker Ascend $400 \mathrm{MHz}$, Billerica, MA, USA) at $400 \mathrm{MHz}, 7.05 \mathrm{~T}$, and $25^{\circ} \mathrm{C}$. The samples were analyzed utilizing deuterium oxide as the solvent reference. Spectra were acquired in $1.73 \mathrm{~s}$, employing 16 scans. The structural characterization of the products was also confirmed by infrared spectroscopy (GX-FTIR, PerkinElmer, Waltham, MA, USA) using the ATR accessory. Spectra were studied in the region from 4000 to $400 \mathrm{~cm}^{-1}$, performing 30 scans, with a resolution of $4 \mathrm{~cm}^{-1}$. The molecular weight of Poly(Ani-AMPS) was determined by employing a gel permeation chromatographer (1260 Infinity, Agilent, Santa Clara, California, USA) with a refractive index detector. The equipment had three columns in molecular weight ranges from 100 to $30,000 \mathrm{~g} / \mathrm{mol}, 10,000$ to $200,000 \mathrm{~g} / \mathrm{mol}$, and 50,000 to 1,000,000 g/mol. The mobile phase was a pH 8 buffer solution $\left(\mathrm{NaNO}_{3} 0.2 \mathrm{M}, \mathrm{NaH}_{2} \mathrm{PO}_{4} 0.01 \mathrm{M}, \mathrm{NaN}_{3} 100 \mathrm{ppm}\right)$. Ten standards samples of poly(ethylene glycol) $\left(\mathrm{M}_{\mathrm{p}}=106 \mathrm{~g} / \mathrm{mol}\right.$ lower limit, $\mathrm{M}_{\mathrm{p}}=21,300 \mathrm{~g} / \mathrm{mol}$ higher limit) were used for calibration purposes. Fluorescence properties from Poly(Ani-AMPS) were performed on a fluorescence spectrometer (PerkinElmer LS-45, Waltham, MA, USA). In addition, the concentrations of Poly(Ani-AMPS) and binary metallic salts were $500 \mathrm{ppm}$ and $1 \mathrm{mM}$, respectively. The study of optical properties was achieved by UV-Vis-NIR (Evolution 220, Thermo Fisher Scientific, Waltham, MA, USA) spectroscopy. The thermal degradation of the samples $(10 \mathrm{mg})$ was characterized using a thermal analyzer (SDT Q600, TA Instruments, New Castle, DE, USA) under air atmosphere. Measurements were performed at a heating rate of $10^{\circ} \mathrm{C} \mathrm{min}^{-1}$ from room temperature to $700{ }^{\circ} \mathrm{C}$. A differential scanning calorimeter (DSC Q2000, TA Instruments, New Castle, DE, USA) was utilized to measure the glass transition temperature $\left(T_{g}\right)$ in order to contrast the Poly(Ani-AMPS) value with Poly(AMPS-acid). Specifically, $10 \mathrm{mg}$ of sample was used under a nitrogen atmosphere at a heating rate of $10^{\circ} \mathrm{C} \mathrm{min}^{-1}$. The morphological analyses of Poly(Ani-AMPS) and PAni-AMPS were performed using a field emission scanning electron microscope (FE-SEM, JSM-7401F, JEOL, Akishima, Japan) equipped with an r-filter that allowed variable energy to filter secondary electrons and backscattered electrons. 
The electrochemical characteristics of PAni-AMPS were determined utilizing a potentiostat/galvanostate analyzer (Model 1260 plus 1287, Solartron Analytical, Farnborough, Hampshire, UK). The study was conducted with a standard three-electrode cell, where a platinum plate $\left(1 \mathrm{~cm}^{2}\right)$, an $\mathrm{Ag} / \mathrm{AgCl} /$ saturated $\mathrm{KCl}$ electrode, and carbon paste plus a sample film were the counter electrode, reference electrode, and working electrode, respectively. The electrolyte utilized was a sulfuric acid solution $[2.0 \mathrm{M}]$. The potential window was from -0.5 to $+1.0 \mathrm{~V}$ versus $\mathrm{Ag} / \mathrm{AgCl} /$ saturated $\mathrm{KCl}$ electrode at a scan rate of $10 \mathrm{mV} \mathrm{s}^{-1}$.

\section{Results and Discussion}

The selective polymerization that occurs in Ani-AMPS monomer depends mainly on the polymerization conditions. For instance, in free-radical polymerization, a redox initiator is utilized, where sodium metabisulfite (MBS) is first added to produce sodium bisulfite in the presence of water. Thus, salt reacts with ammonium persulfate (APS) to generate free radicals, initiating the polymerization process. It is important to note that sodium bisulfite has a lower oxidation potential than anilinium salts, so APS reacts with sodium bisulfite. In contrast, APS acts as an oxidative agent in oxidative polymerization because the system does not contain MBS. In addition, oxidative polymerization, specifically for PAni-AMPS, requires a molar ratio of 1.25:1 (ammonium persulfate:Ani-AMPS). Compared to free-radical polymerization, oxidative polymerization demands an increased amount of initiator as an oxidizing agent. Figure S4 illustrates the scheme of the decomposition of MBS and its reaction with APS.

\subsection{Monomer Characterization}

The Ani-AMPS monomer synthesis occurs through an acid-base reaction between AMPS-acid and aniline. For structural elucidation, ${ }^{1} \mathrm{H}$ NMR and FTIR spectroscopy were employed; Figure 2A shows the ${ }^{1} \mathrm{H}$ NMR spectrum of Ani-AMPS. The signals at 7.64-7.45 ppm correspond to phenyl protons (type $\mathrm{AB}_{2} \mathrm{X}_{2}$ system), which are characteristic of monosubstituted benzene [24]. Specifically, the $\mathrm{H}_{\mathrm{b}}, \mathrm{H}_{\mathrm{c}}(\mathrm{m}, 7.64-7.54 \mathrm{ppm}, 3 \mathrm{H})$, and $\mathrm{H}_{\mathrm{d}}(\mathrm{dd}, 7.45 \mathrm{ppm}, 2 \mathrm{H})$ protons. The signals of the vinyl protons (system AMX) are $\mathrm{H}_{\mathrm{e}}\left(\mathrm{dd}, 6.26 \mathrm{ppm}, 1 \mathrm{H}, \mathrm{J}_{\mathrm{e}-\mathrm{f}}\right.$ and e-j $\left.=17.1,1.5 \mathrm{~Hz}\right), \mathrm{H}_{\mathrm{f}}\left(\mathrm{dd}, 6.16,1 \mathrm{H}, \mathrm{J}_{\mathrm{f}-\mathrm{j}, \mathrm{f}-\mathrm{e}}=17.1,10.1 \mathrm{~Hz}\right)$, and $\mathrm{H}_{\mathrm{j}}\left(\mathrm{dd}, 5.72 \mathrm{ppm}, 1 \mathrm{H}, \mathrm{J}_{\mathrm{j}-\mathrm{f}, \mathrm{j} \text {-e }}=10.1,1.5 \mathrm{~Hz}\right.$ ) [25]. The spectra also present two more peaks, including the $\mathrm{H}_{\mathrm{g}}$ proton $(\mathrm{s}, 3.44,2 \mathrm{H})$ attributed to the $\alpha$-methylene sulfonate group and, finally, the $\mathrm{H}_{\mathrm{i}}$ proton $(\mathrm{s}, 1.53,6 \mathrm{H})$ was assigned to the $\gamma$-methyl sulfonate group [26].

Figure 2B shows the FTIR spectra of AMPS-acid, aniline, and Ani-AMPS. Compared with AMPS-acid and aniline, the Ani-AMPS presents characteristic bands that validated the anilinium cation formation, specifically at $2638 \mathrm{~cm}^{-1}$ and $1157 \mathrm{~cm}^{-1}$, associated, respectively, with an overtone and stretching vibration of the ${ }^{+} \mathrm{N}-\mathrm{H}$ and $\mathrm{C}-\mathrm{N}^{+}$bond [15]. It is essential to note the significant change in the vibration corresponding to C-N of the Ani-AMPS to its C-N ${ }^{+}$ form present in the polymer. Additionally, the peaks of AMPS anion functional groups are present in the monomer, such as the secondary amide exhibiting a band at $3276 \mathrm{~cm}^{-1}$ due to $\mathrm{N}-\mathrm{H}$ stretching vibrations [27]. Notably, in this region $\left(3370-3270 \mathrm{~cm}^{-1}\right)$, the amides in a solid or liquid state may have bands due to hydrogen bonds.

For the methyl groups, the symmetric stretching and asymmetric deformation vibrations of C-H occur near $2875 \mathrm{~cm}^{-1}$ and at $1465 \mathrm{~cm}^{-1}$, respectively. The stretching vibration corresponding to the carbonyl group is shown at $1654 \mathrm{~cm}^{-1}$. The alkene absorption (type stretching vibration) band occurs at a wavenumber of $1620 \mathrm{~cm}^{-1}$. Additionally, the spectrum presented bands at $1041 \mathrm{~cm}^{-1}$ and $1177 \mathrm{~cm}^{-1}$, correlated, respectively, with the symmetric stretching vibration of $\mathrm{S}-\mathrm{O}$ and symmetric flexion of $\mathrm{S}=\mathrm{O}$ of the $\mathrm{SO}_{3}$ group [28]. Based on this characterization, the formation of Ani-AMPS can be confirmed. 
A)<smiles>CC=CC(=O)NC(C)(C)CC(C)(C)CS(=O)(=O)Nc1ccccc1</smiles>
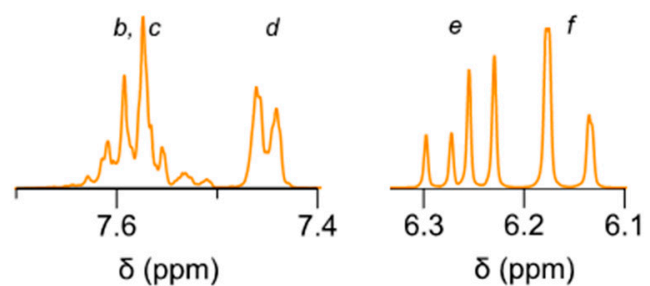

$\mathrm{D}_{2} \mathrm{O}$
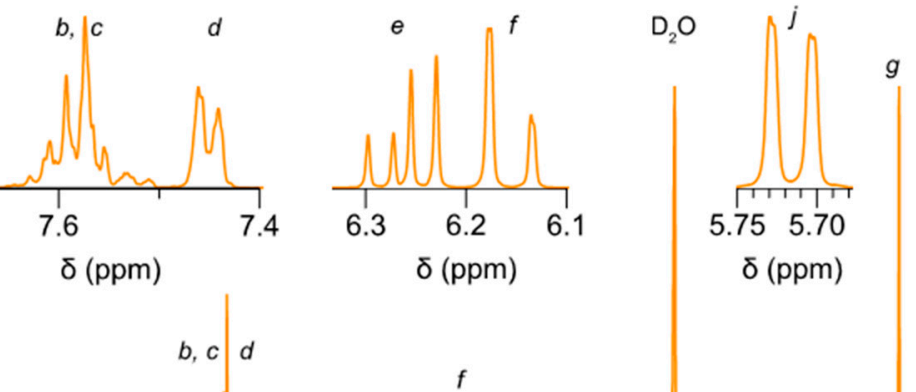

$\delta(\mathrm{ppm})$

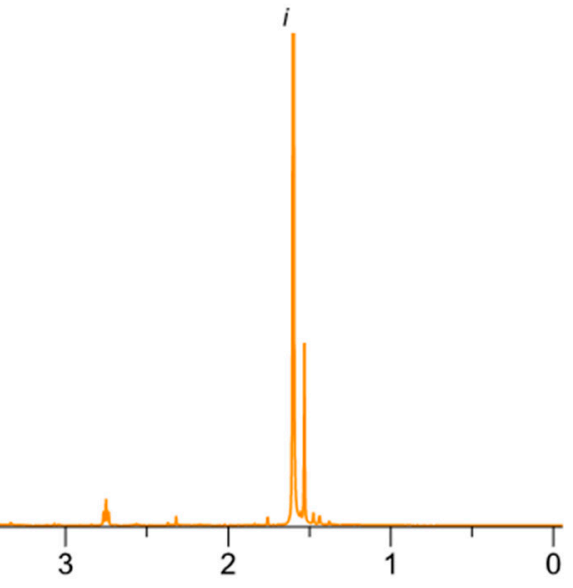

в)

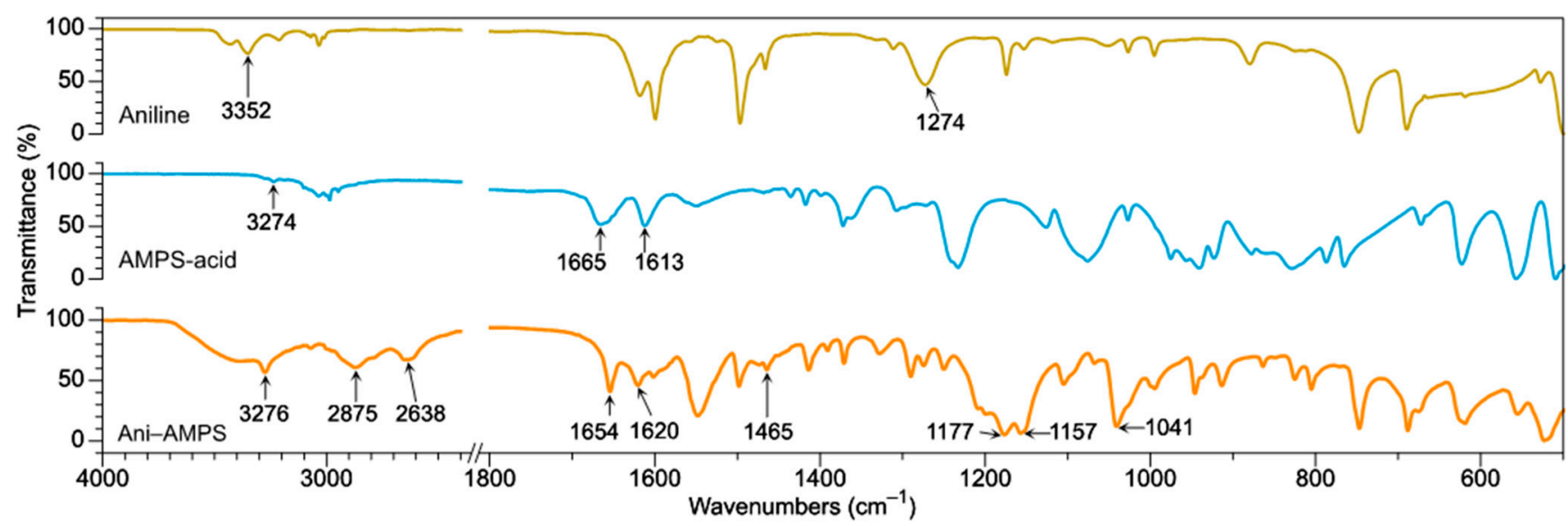

Figure 2. Ani-AMPS monomer spectra: (A) ${ }^{1} \mathrm{H}$ NMR (solvent: deuterium oxide) $\delta 7.64-7.54(\mathrm{~m}, 3 \mathrm{H}), 7.45(\mathrm{dt}, J=8.0,1.5 \mathrm{~Hz}, 2 \mathrm{H})$, $6.26(\mathrm{dd}, J=17.1,10.1 \mathrm{~Hz}, 1 \mathrm{H}), 6.16(\mathrm{dd}, J=17.1,1.5 \mathrm{~Hz}, 1 \mathrm{H}), 5.72(\mathrm{dd}, J=10.1,1.5 \mathrm{~Hz}, 1 \mathrm{H}), 3.44(\mathrm{~s}, 2 \mathrm{H}), 1.53(\mathrm{~s}, 6 \mathrm{H})$ and (B) FTIR spectra, comparison of Ani-AMPS versus aniline and AMPS-acid.

\subsection{Characterization of the Product of Free-Radical Polymerization}

The free-radical polymerization of the Ani-AMPS occurs over the vinyl group, forming an aliphatic chain. The polymer product, Poly(Ani-AMPS), was characterized by ${ }^{1} \mathrm{H}$ NMR and ${ }^{13} \mathrm{C}$ NMR spectroscopy to confirm the polymer structure, as shown in Figure S2. Figure 3a illustrates the ${ }^{1} \mathrm{H}$ NMR of Poly(Ani-AMPS) utilizing deuterium oxide as a solvent. It is interesting to note that the ${ }^{1} \mathrm{H}$ NMR spectrum integration and the number of signals corresponding to ${ }^{13} \mathrm{C}$ NMR are equivalent to two monomers, as shown in Figure S2. Furthermore, the spectrum also presents four new signals at a high field associated with $\mathrm{H}_{\mathrm{e}}, \mathrm{H}_{\mathrm{f}}$, and $\mathrm{H}_{\mathrm{j}}$ protons, due to the hybridization change from $\mathrm{sp}^{2}$ to $\mathrm{sp}^{3}$ caused by the polymerization process [26]. The proton $\left(\mathrm{H}_{\mathrm{e}}\right)$ has two identical triplets at $3.59 \mathrm{ppm}(1 \mathrm{H})$ and $2.55 \mathrm{ppm}(1 \mathrm{H})$ assigned like $\mathrm{H}_{\mathrm{e}}$ and $\mathrm{H}_{\mathrm{e}^{*}}$ (only to differentiate protons), respectively. The $\mathrm{H}_{\mathrm{f}}$ and $\mathrm{H}_{\mathrm{j}}$ protons are presented as broad bands located at $1.98 \mathrm{ppm}(2 \mathrm{H})$ and $1.62 \mathrm{ppm}(2 \mathrm{H})$, corresponding to $\mathrm{H}_{\mathrm{f}}+\mathrm{H}_{\mathrm{j}}$ and $\mathrm{H}_{\mathrm{f}^{*}}+\mathrm{H}_{\mathrm{j}^{*}}$, respectively. Therefore, the similarity in the shape, pattern, and integration of these signals suggests the formation of a complex structure. The spectrum also shows a multiplet and doublet $(7.55-7.25 \mathrm{ppm}, 10 \mathrm{H})$ corresponding to aromatic protons of two anilinium cations. Compared with the Ani-AMPS, Poly(AniAMPS) aromatic proton signals appear at a high field close to $0.2 \mathrm{ppm}$. These changes, specifically in the region of the aromatic ring peaks, are due to $\pi$-stacking interactions, forming more complex structures known as self-assembly. Several reports on this effect employed different strategies, especially the increase in the number of aromatic ring 
substitutes and the concentration concerning $\pi$-stacking. Consider, as an example, the selfassociation between pyridine and benzene functionalized with bis-pyrene methyl amide, induced by hydrogen bonding and $\pi$ interactions, according to Kim et al. [29]. Another path, $\pi$-stacking, was evident by the shift from aromatic protons to higher fields when the sample concentration was studied based on these interactions [30].

a)<smiles>CC(C)(CS(=O)(=O)[NH2+]c1ccccc1)NC(=O)C(C(C)(C)C)C(C)(C)C</smiles>

b)

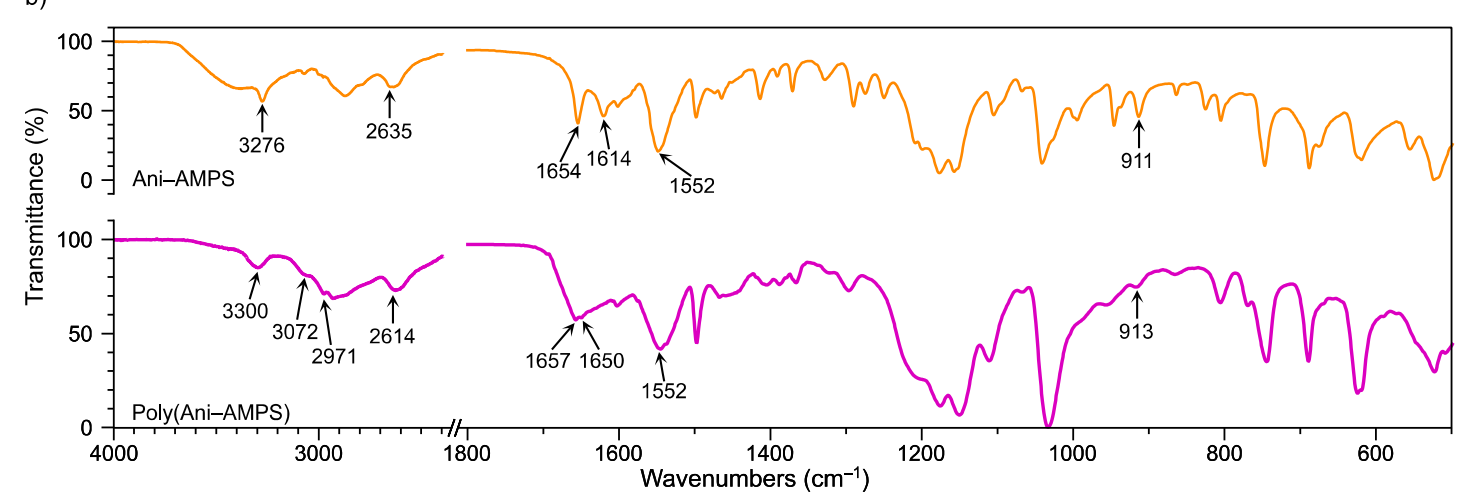

Figure 3. Poly(Ani-AMPS) spectra: (a) ${ }^{1} \mathrm{H}$ NMR (solvent: deuterium oxide) $\delta 7.80-7.29(\mathrm{~m}, 10 \mathrm{H}), 3.71(\mathrm{t}, J=6.3 \mathrm{~Hz}, 1 \mathrm{H})$, 3.49-3.25 (m, 4H), $2.67(\mathrm{t}, \mathrm{J}=6.3 \mathrm{~Hz}, 1 \mathrm{H}), 2.10(\mathrm{~m}, 2 \mathrm{H}), 1.82-1.55(\mathrm{~m}, 2 \mathrm{H}), 1.53-1.43(\mathrm{~m}, 12 \mathrm{H}) ;$ * Equivalent protons with different conformation, and (b) FTIR spectra, comparison of the Poly(Ani-AMPS) versus the Ani-AMPS monomer.

The structural validation of Poly(Ani-AMPS) was corroborated by FTIR spectroscopy, compared with Ani-AMPS. Figure 3b shows the Ani-AMPS and Poly(Ani-AMPS) spectra. The Poly(Ani-AMPS) has substantially decreased molecular vibrations, particularly in the aromatic fingerprint, suggesting $\pi$-stacking interactions. For instance, the aromatic $\mathrm{C}-\mathrm{H}$ out-ofplane deformation vibrations at 865,825 , and $690 \mathrm{~cm}^{-1}$. The C-C stretching vibrations of the aromatic ring also have an identical effect, particularly at 1575 and $1475 \mathrm{~cm}^{-1}$. Additionally, Ovchinnikov et al. reported the formation of $\pi$-stacking interaction and self-association of methylene blue in the region at high vibrational frequency [31]. Specifically, a significant change was observed regarding the shape of the absorption band at $3072 \mathrm{~cm}^{-1}$ for Poly(AniAMPS), ascribed to C-H stretching vibrations of the aromatic group. Lastly, to complement Poly(Ani-AMPS) characterization, the molecular weight was determined by GPC. Mw of $9345 \mathrm{~g} / \mathrm{mol}$ and a polydispersity index of 4.39 were obtained. It is important to note that this molecular weight corresponds to the polyanion due to the $\mathrm{pH}$ of the mobile phase.

Moreover, the C-C stretching $\left(1620 \mathrm{~cm}^{-1}\right)$ and C-H deformation vibrations concerning the alkene functional group decreased because of polymerization. Particularly, near $913 \mathrm{~cm}^{-1}$, corresponding to $\mathrm{CH}_{2}$ out-of-plane deformation vibration, and the region from $970-940 \mathrm{~cm}^{-1}$, corresponding to $\mathrm{C}-\mathrm{H}$ out-of-plane deformation vibration [32]. Additionally, the $\mathrm{C}-\mathrm{H}$ (methyl group) asymmetric stretching vibration occurs at $2976 \mathrm{~cm}^{-1}$. For the $\alpha$-methylene sulfonate group, two bands are observed at $2926 \mathrm{~cm}^{-1}$ and about $2870 \mathrm{~cm}^{-1}$, corresponding to the 
asymmetric and symmetric C-H stretching vibration, respectively. Further, an overlap (around $2870 \mathrm{~cm}^{-1}$ ) corresponding to the symmetric stretching vibration band for the methyl and $\alpha$-methylene sulfonate group is observed. A shift of about $21 \mathrm{~cm}^{-1}$ at most is observed for the ${ }^{+} \mathrm{N}-\mathrm{H}$ bond (anilinium group) in the Poly(Ani-AMPS) spectrum.

A broad band is observed around $1650 \mathrm{~cm}^{-1}$ because the Poly(Ani-AMPS) sample contained water that was difficult to remove, so the peaks corresponding to the stretching and flexion vibration for $\mathrm{C}=\mathrm{O}\left(1654 \mathrm{~cm}^{-1}\right)$ and $\mathrm{N}-\mathrm{H}\left(1552 \mathrm{~cm}^{-1}\right)$ are not defined as in the Ani-AMPS monomer [33].

\subsection{Photoluminescence Properties of Poly(Ani-AMPS)}

The fluorescence of the materials could be modified in the presence of metals, anions, or cations, or the change in solvent polarity [34]. For example, Figure 4a shows the spectrum of Poly(Ani-AMPS) in an aqueous solution at $550 \mathrm{ppm}$. The Poly(Ani-AMPS) presents two excitation peaks with a maximum at $278 \mathrm{~nm}$ and the emission peak at $347 \mathrm{~nm}$, corresponding to $\pi-\pi^{*}$ transitions of the aromatic ring (anilinium cation) [35].

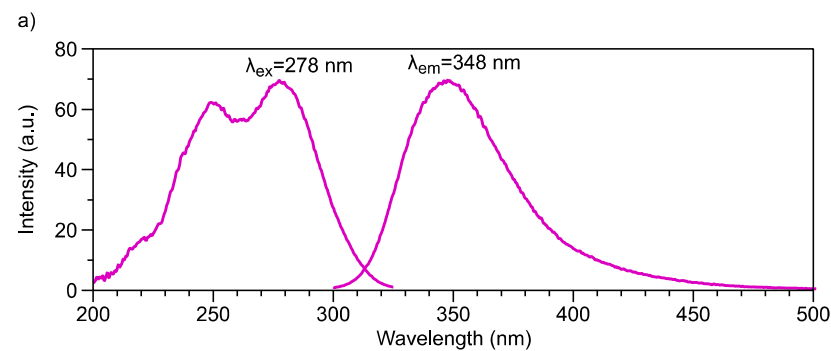

b)

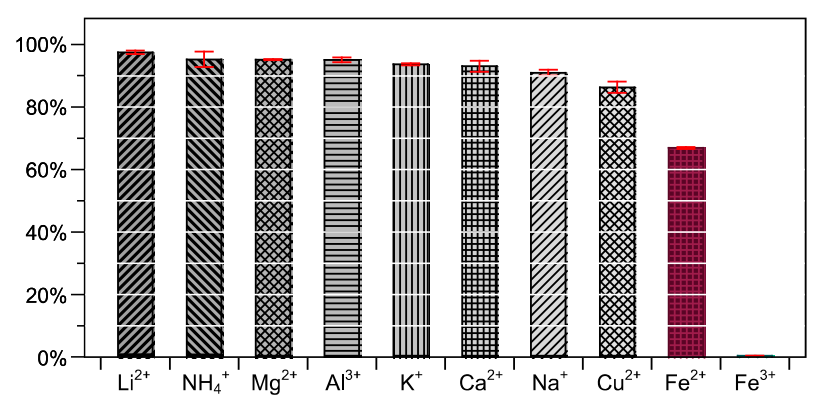

Figure 4. (a) Fluorescence spectrum of Poly(Ani-AMPS), (b) percentage of emission spectrum turn-off signal evaluating the Poly(Ani-AMPS) interaction with some ions.

The fluorescent properties of Poly(Ani-AMPS) were investigated when analyzing the interaction between the aromatic ring (anilinium cations) and chloride salt. It is worth saying that using a fluorescent sensor is a convenient method to analyze metal ions due to their high sensitivity and easy operability [36,37]. To analyze the effect of different metal ions on the fluorescence of the polymer, several aqueous solutions were prepared utilizing chloride salts $\left(\mathrm{Al}^{3+}, \mathrm{Na}^{+}, \mathrm{Mg}^{2+}, \mathrm{Li}^{+}, \mathrm{K}^{2+}, \mathrm{Cu}^{2+}, \mathrm{Ca}^{2+}, \mathrm{Fe}^{2+}, \mathrm{Fe}^{3+}, \mathrm{NH}^{4+}\right)$ as solutes at $1 \mathrm{mM}$ concentration. The study was based on the reduction of the emission peak, evidencing the interaction with binary salt. Figure $4 \mathrm{~b}$ displays the percentage of quenching with the different ions analyzed. The Poly(Ani-AMPS) presented a selectivity quenching for $\mathrm{Fe}^{2+}$ and $\mathrm{Fe}^{3+}$ [36]. The fluorescence turn-off was attributed to coordination interactions between aromatic rings (anilinium cations) and $\mathrm{Fe}^{2+}$ or $\mathrm{Fe}^{3+}$ [38]. To summarize, from a quantum mechanics point of view, it suggests that it takes precedence over orbital $d$ cations under these conditions. It is important to note that iron cations play a fundamental role in biological and environmental processes.

The detection limit for $\mathrm{Fe}^{2+}$ and $\mathrm{Fe}^{3+}$ was determined at several concentrations. Figure 5a,c illustrate the abatement in the fluorescence signal of the emission spectrum and the correlation of maximum intensity at $348 \mathrm{~nm}$ versus concentration for $\mathrm{Fe}^{2+}$ and $\mathrm{Fe}^{3+}$. The limit of detection 
is $500 \mu \mathrm{M}$ and $20 \mu \mathrm{M}$, respectively, for $\mathrm{Fe}^{2+}$ and $\mathrm{Fe}^{3+}$. The behavior, in general, presented two linear zones with different concentration intervals. Figure $5 \mathrm{~b}$ shows the fluorescence intensity of the emission spectrum regarding the concentration of $\mathrm{Fe}^{2+}$. The first and second zone are located from $0 \mu \mathrm{M}$ to $1000 \mu \mathrm{M}$ and from $1000 \mu \mathrm{M}$ to $4000 \mu \mathrm{M}$. Nevertheless, for the $\mathrm{Fe}^{3+}$ system, the Poly(Ani-AMPS) has significant selectivity compared with the analogous $\mathrm{Fe}^{2+}$. Figure $5 \mathrm{~b}$ displays the two linear zones, where the first is from $20 \mu \mathrm{M}$ to $80 \mu \mathrm{M}$, and the second region is from $100 \mu \mathrm{M}$ to $400 \mu \mathrm{M}$ [39]. Table S1 displays the values of fluorescence intensity concerning concentration for $\mathrm{Fe}^{2+}$ and $\mathrm{Fe}^{3+}$. The different behavior of both cations is due to solubility in water $\left(\mathrm{Fe}^{3+}>>\mathrm{Fe}^{2+}\right)$, with the solvent playing an important role when sensing [40].
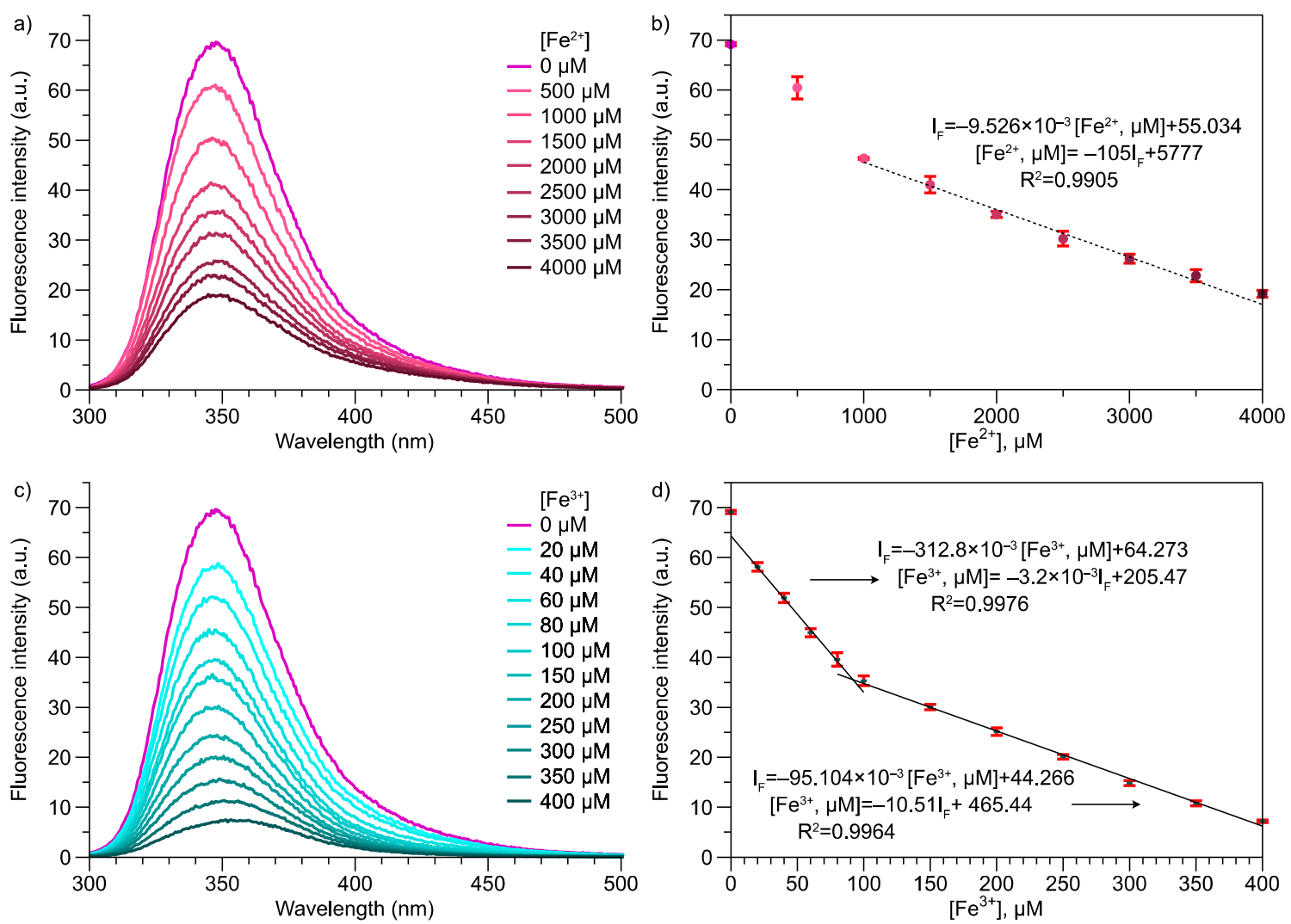

Figure 5. Poly(Ani-AMPS) fluorescence emission spectra regarding the concentration of (a) $\mathrm{Fe}^{2+}$ and (c) $\mathrm{Fe}^{3+}$. The plot of the emission intensity at $348 \mathrm{~nm}$ vs. the concentration of (b) $\mathrm{Fe}^{2+}$ and (d) $\mathrm{Fe}^{3+}$.

The sensitivity of the polymer is comparable with previous reports; however, its detection range is higher than most of the reported ranges [37,41,42]. For example, Chen et al. reported that the synthesis of polyphosphazene microspheres has selectivity for $\mathrm{Fe}^{3+}$ aqueous solutions and a detection limit of $76 \times 10^{-9} \mathrm{M}(0.076 \mu \mathrm{M})$ in a range from 0 to $10 \mu \mathrm{M}$ [37]. Additionally, Yang et al. reports sensitivity for $\mathrm{Fe}^{3+}$ in $N, N$ dimethylformamide solutions, presenting a detection limit of $0.21 \mu \mathrm{M}$ [0.21 to $150 \mu \mathrm{M}$ ], using Eu-based coordination polymer, including 4-(pyridyl-N-oxide) methylphosphonic acid as a ligand [43].

\subsection{Oxidative Polymerization}

The Ani-AMPS monomer can be polymerized through an oxidative mechanism, producing polyaniline doped with 2-acrylamide-2-methyl-1-propanesulfonate (PAni-AMPS). Contrary to the Poly(Ani-AMPS) structure, PAni is the polymer backbone, and AMPS anion is the dopant. The analysis of chemical structures and electroactive properties of PAni-AMPS was confirmed by FTIR spectroscopy and cyclic voltammetry, as shown in Figure 6. Typical molecular vibrations reported for PAni are observed; for example, $1584 \mathrm{~cm}^{-1}$ and $1488 \mathrm{~cm}^{-1}$ were assigned to the stretching vibrations of the $\mathrm{C}=\mathrm{N}$ bond of the quinoid ring and the $\mathrm{C}-\mathrm{N}$ bond of the benzenoid ring, respectively $[44,45]$. The peak height of the benzoid group is higher than the quinoid 
structure, suggesting the presence of PAni in the form of emeraldine salt [46]. The spectrum also presents a signal at $810 \mathrm{~cm}^{-1}$ assigned to the $p$-benzene ring disubstituted position. These three signals confirmed the backbone formation [47]. In addition, the spectrum shows the characteristic peaks of AMPS anion, for instance, at $1664 \mathrm{~cm}^{-1}$ and $1552 \mathrm{~cm}^{-1}$ described previously for the amide group. The presence of these signals indicates the formation of PAni doped with the AMPS anion [48].
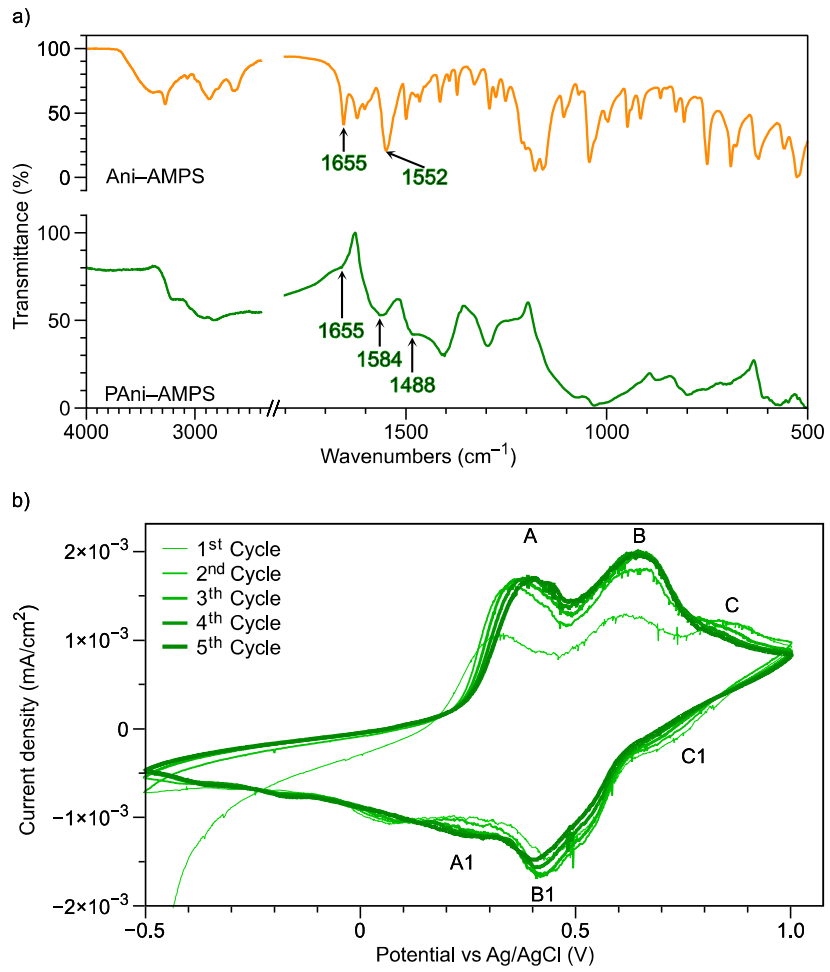

Figure 6. PAni-AMPS characterization by (a) FTIR spectroscopy, comparison of PAni-AMPS versus Ani-AMPS spectra, and (b) cyclic voltammetry in three-electrode system utilizing sulfuric acid $[1 \mathrm{mM}]$ as an electrolyte.

The electroactivity is characteristic in conductive polymers; consequently, PAniAMPS was studied. Figure $6 \mathrm{~b}$ shows the cyclic voltammogram of PAni-AMPS utilizing sulfuric acid $[1 \mathrm{mM}]$ as the electrolyte, in the potential window from -0.5 to $1.0 \mathrm{~V}$. As noted, three oxidation signals at $0.325(\mathrm{~A}), 0.62(\mathrm{~B})$, and $0.86 \mathrm{~V}(\mathrm{C})$ are present. The peaks $\mathrm{A} / \mathrm{A} 1$ and $\mathrm{C} / \mathrm{C} 1$ were attributed to the redox transitions leucoemeraldine/emeraldine and emeraldine/pernigraniline, respectively [49]. Specifically, peak A presents an increase and displacement towards positive potential, comparing the first against the fifth cycle. Additionally, this minor change is related to the exchange of dopants between the AMPS and the electrolyte dopant agent $\left(\mathrm{HSO}_{4}\right)^{-}$[50]. The transition emeraldine/pernigraniline (peak $\mathrm{C}$ ) decreased relative to the number of cycles due to the doping exchange, overlapping with peak B, causing an increase in current density. Peak B, in the fifth cycle, shows a maximum current density at $0.68 \mathrm{~V}$. Compared to peak $\mathrm{B}$, the oxidation peak of PAni- $\left(\mathrm{HSO}_{4}\right)^{-}$for transition emeraldine/pernigraniline was reported at $0.72 \mathrm{~V}$, confirming dopant exchange [51]. Additionally, dimers or polymer hydrolysis formation owing to the electrolyte is observed at peak B/B1 [52].

Several applications of electroactive PAni, such as in electrodes [53], supercapacitors [54], sensors [55], conductive inks, anticorrosive coatings, and conductive surfaces [56,57], have been demonstrated. Therefore, PAni-AMPS has the potential for application in these areas. 


\subsection{Comparison of Poly(Ani-AMPS) and PAni-AMPS}

\subsubsection{Optical Properties}

The role of the anilinium cation in the structure of the two polymers is altogether different, e.g., for Poly(Ani-AMPS), it acts as the counterion, and for PAni-AMPS, it constitutes the backbone. These significant changes in basic chemical structure reflect differences in optical properties, according to UV-Vis-NIR spectroscopy. Figure 7a shows the UV-Vis-NIR spectra of Ani-AMPS, Poly(Ani-AMPS), and PAni-AMPS in an aqueous solution at a concentration of $660 \mathrm{ppm}$. The spectrum of Ani-AMPS presents a shoulder signal at $285 \mathrm{~nm}$, corresponding to $\pi-\pi^{*}$ of the aromatic ring (anilinium cation). Compared with Ani-AMPS, the Poly(Ani-AMPs) shows two signals at 285 and $352 \mathrm{~nm}$. Similarly to Ani-AMPS, the shoulder signal at $285 \mathrm{~nm}$ was assigned to $\pi-\pi^{*}$ of the aromatic ring [58]. Furthermore, the band at $352 \mathrm{~nm}$ was attributed to the $\pi$-stacking effect that occurs in anilinium cations through the aromatic ring, forming the Poly(Ani-AMPS) complex structures $[10,14,15]$. It should be noted that the shoulder observed for the monomer and its polymer close to $285 \mathrm{~nm}$ was confirmed with the first derivative of each spectrum, as shown in Figure 7a.

a)

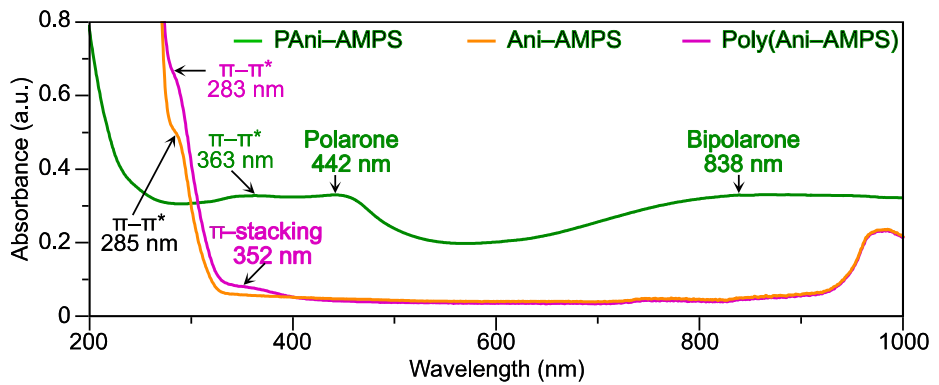

b)

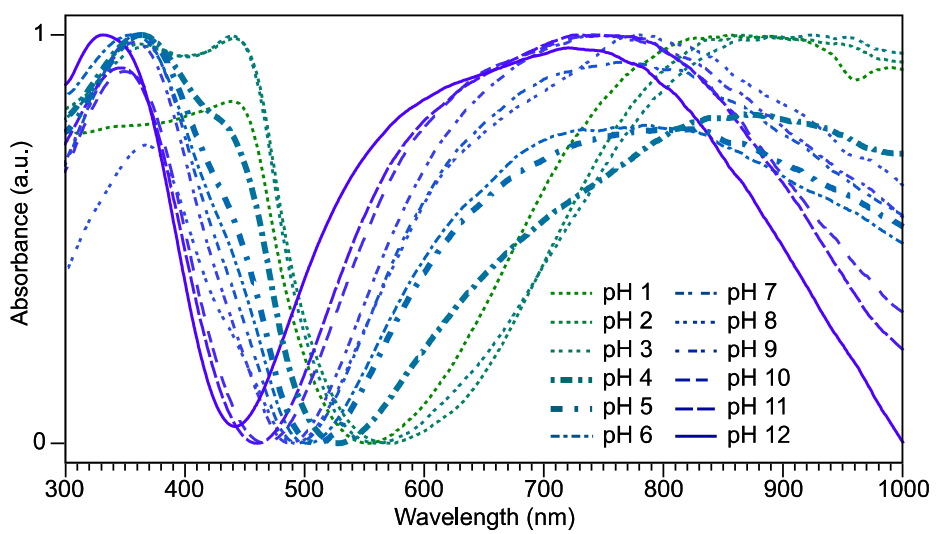

c)

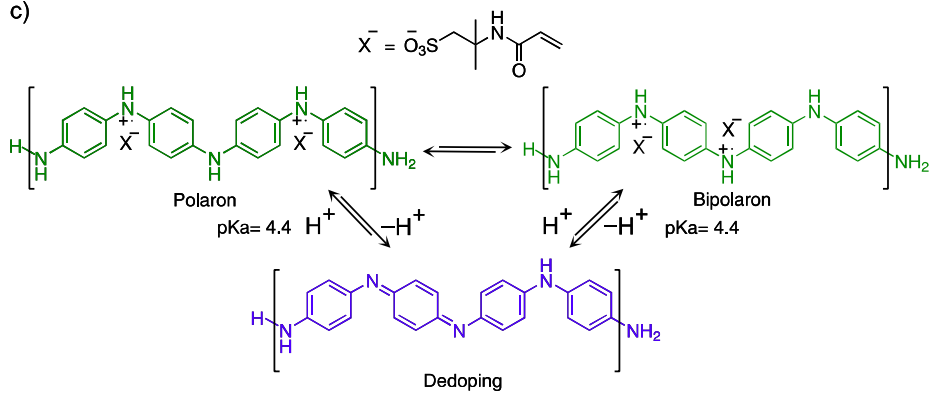

Figure 7. (a) UV-Vis-NIR spectra of Ani-AMPS, Poly(Ani-AMPS), and PAni-AMPS; (b) UV-Vis-NIR spectra of PAni-AMPS at different $\mathrm{pH}$. (c) Scheme of doped-dedoped PAni-AMPS.

Moreover, the PAni-AMPS spectrum, shown in Figure 7a, presents the typical bands of emeraldine salt, i.e., at $363 \mathrm{~nm}$ assigned to the benzenoid structure, at $442 \mathrm{~nm}$ to the polaron transition, and finally, a broad band from 700 to $1000 \mathrm{~nm}$, where the bipolar transition 
at $790 \mathrm{~nm}$ is observed [59,60]. The color of the PAni-AMPS is dark green, in the state of emeraldine salt, produced by polaron-bipolaron equilibrium, and also gives the conductive properties to polyaniline [61].

Polyaniline is employed as a colorimetric $\mathrm{pH}$ sensor based on a fundamental chemical principle causing the removal of the dopant agent and, therefore, a polymer color change. In addition, the point where color alteration occurs is associated with $\mathrm{pKa}$ of doped polyaniline, which indicates the loss of the dopant agent. To determine the $\mathrm{pH}$ at which the PAni-AMPS doping-dedoping (color change) occurs, UV-Vis-NIR spectra were obtained from $\mathrm{pH} 1$ to 12 , as shown in Figure $7 \mathrm{~b}$. It is clear that the polaron and bipolaron signals are present at an acid $\mathrm{pH}$ of less than 4 . At $\mathrm{pH} 5$, the polaron signal intensity decreases significantly, and the broad band of bipolaron starts to shift to blue. When the polaron signal presents half of the intensity concerning $\mathrm{pH} 1$ (maximum) and $\mathrm{pH} 12$ (minimum), the $\mathrm{pKa}$ for the PAni-AMPS was determined at 4.4, as shown in Figure $7 \mathrm{~b}$. The spectra from $\mathrm{pH} 6$ to 12 show that the broad band is located from 500 to $900 \mathrm{~nm}$ with a shoulder peak at $\sim 660 \mathrm{~nm}$ assigned to the quinoid ring of the emeraldine base, the nonconductive form of polyaniline, with the characteristic blue color.

The $\pi$-stacking effect has been investigated in several molecules, analyzing solvent type, concentration, and time, among other variables [62-64]. Additionally, UV-Vis spectroscopy is one of the characterization techniques for identifying the presence of $\pi$-stacking [65]. This effect in Poly(Ani-AMPS) is produced by the inter- or intra-chain or both interactions among the anilinium cations, AMPS anion, and solvent. The equilibrium forces between the AMPS anion and anilinium cation (van der Waals forces, electrostatic repulsion, steric hindrance) allow the interaction and the final conformation, too $[62,66]$.

Previously, a polar solvent was selected with different functional groups, such as alcohol, ketone, and carboxylic acid. The solvents selected were acetone, ethanol, formic acid, and water, which present a dielectric constant of 20.7,36.4, 58, and 80.4, respectively. The purpose was to find whether the solvent types keep the cation anilinium stable with the polymer. Figure 8a illustrates the UV-Vis-NIR spectra of solutions of Poly(Ani-AMPS) in these solvents at a concentration of $660 \mathrm{ppm}$. For acetone, the spectrum shows bands at 264, 286 , and $306 \mathrm{~nm}$, assigned to the transitions $n-\pi^{*}$ of the nitrogen of the anilinium cation, $\pi$ $\pi^{*}$ of the aromatic ring, and $n-\pi^{*}$ of oxygen in the acetone, respectively. The last signal was interpreted as the electrostatic interaction between the polymer and acetone. The spectra of water and ethanol were similar, only presenting a band around $285 \mathrm{~nm}$, attributed to the aromatic ring of the anilinium cation. On the other hand, formic acid demonstrates a band at $254 \mathrm{~nm}$, associated with the $\mathrm{n}-\pi^{*}$ transition of oxygen from the carboxylic group; consequently, the absence of the aromatic ring suggested that the acid media protonated the polymer, producing counterion exchange, contrary to water or ethanol, that did not interact or modify the polymer. In summary, Poly(Ani-AMPS) stability, specifically the anilinium cation, is not affected by alcohol or water.

The effects of alcohol-type solvents and water on the $\pi$-stacking of the Poly(AniAMPS) were studied. Figure $8 \mathrm{~b}$ shows the spectrum of Poly(Ani-AMPS) solution in water and several alcohols, i.e., methanol, ethanol, 1-propanol, 2-propanol, and 1-butanol, at a concentration of $660 \mathrm{ppm}$. In general, UV-Vis-NIR spectra of alcohol solutions presented a hyperchromic effect at $352 \mathrm{~nm}$ compared with the analog of the aqueous solution. This behavior is due to increased interactions of the anilinium cation caused by the dielectric constant of the alcohols, producing the $\pi$-stacking effect. The butanol solution presented the highest absorbance at $352 \mathrm{~nm}$ and therefore stimulated the $\pi$-stacking effect. Hence, alcohols with a lower dielectric constant present stronger $\pi$-stacking interactions than alcohols with higher values [67]. 


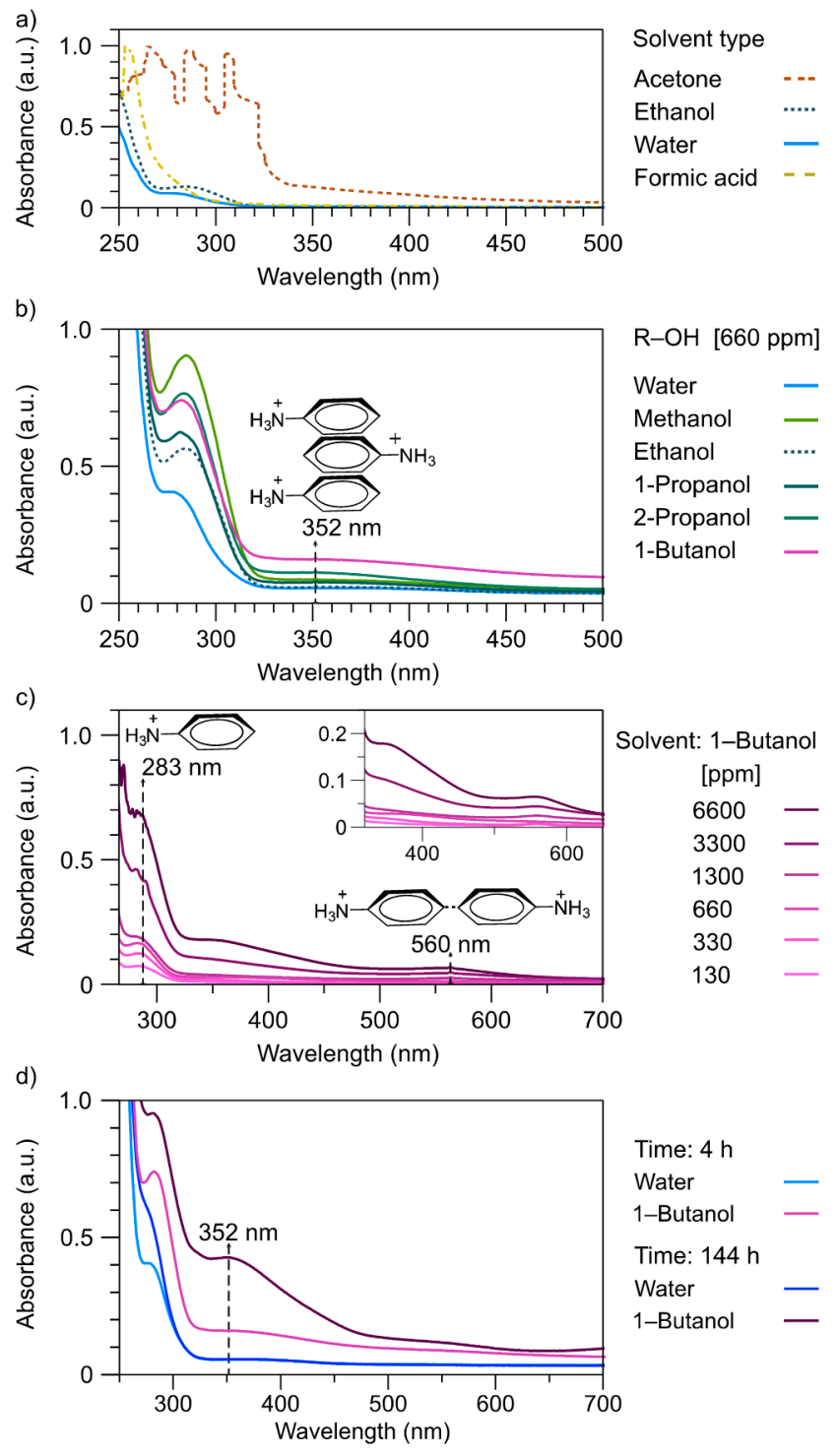

Figure 8. UV-Vis spectra of Poly(Ani-AMPS) in (a) different solvents, (b) different alcohols, (c) different concentrations for $4 \mathrm{~h}$, (d) different times (4 and $144 \mathrm{~h}$ ) at a concentration of $660 \mathrm{ppm}$.

The physical interactions that favored the $\pi$-stacking conformation are related to the concentration of the solution and time. Figure 8c illustrates the UV-Vis spectra of Poly(AniAMPS) solution in butanol at different concentrations, from 130 to $6600 \mathrm{ppm}$, for $4 \mathrm{~h}$. It is evident that the band at $352 \mathrm{~nm}$ depends solely on the polymer concentration, and hence the formation of $\pi$-stacking interactions. Additionally, the dimer generation is attributed to the band that appears at $560 \mathrm{~nm}$, particularly above $1300 \mathrm{ppm}$. Petr et al. reported that at a concentration above $1300 \mathrm{ppm}$, a band at $555 \mathrm{~nm}$ is observed, attributed to the oxidation process of anilinium cations to form dimers or oligomer analog N1-phenylbenzene-1,4-diamine [68].

Moreover, Figure $8 \mathrm{~d}$ shows the spectra at two analysis times (4 and $144 \mathrm{~h}$ ) when employing butanol and water as the solvents, at a concentration of $660 \mathrm{ppm}$. Compared with Poly(Ani-AMPS) solution in water ( $4 \mathrm{~h}$ and $144 \mathrm{~h})$, the Poly(Ani-AMPS) solution in butanol, under identical conditions, has absorbance that is 2.2- and 4-fold higher, for $4 \mathrm{~h}$ and $144 \mathrm{~h}$, respectively. In the case of the water system, there are insignificant changes when comparing $4 \mathrm{~h}$ against $144 \mathrm{~h}$. On the contrary, the Poly(Ani-AMPS) solution in butanol increased about 2 -fold. Therefore, the concentration and time increment, especially for butanol, stimulated chain interactions and the $\pi$-stacking effect on Poly(Ani-AMPS). 


\subsubsection{Thermal Analysis}

Figure 9 shows the thermogravimetric traces of Ani-AMPS, Poly(Ani-AMPS), and PAni-AMPS. The thermal degradation of Ani-AMPS, shown in Figure 9a, occurred in three steps. The first weight loss between 170 and $250{ }^{\circ} \mathrm{C}$, corresponding to $31 \%$, was assigned to anilinium ion degradation [15,69]. The second drop, between 250 and $340{ }^{\circ} \mathrm{C}$, corresponded to desulfonation [70], and the last transition was assigned to vinyl-amide thermal degradation, occurring between 340 and $540{ }^{\circ} \mathrm{C}$ [71].

a)

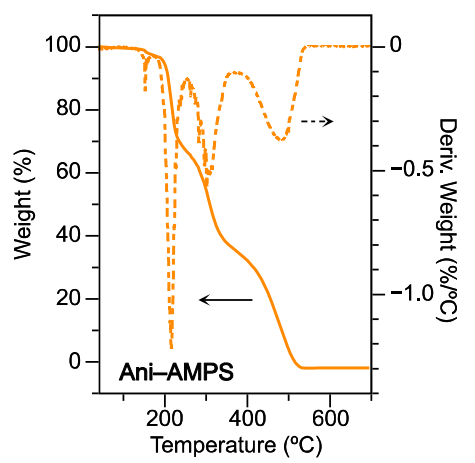

c)

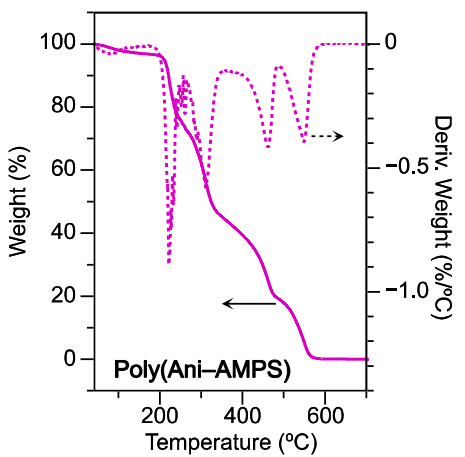

b)

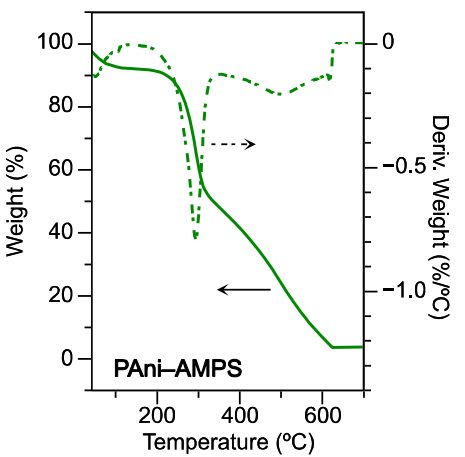

d)

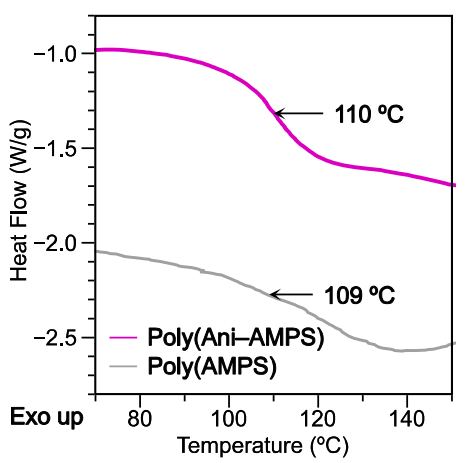

Figure 9. TGA traces and weight derivative of (a) Ani-AMPS, (b) PAni-AMPS, (c) Poly(Ani-AMPS), and (d) glass transition temperatures $\left(\mathrm{T}_{\mathrm{g}}\right)$ of Poly(Ani-AMPS) and Poly(AMPS-acid).

Figure $9 \mathrm{~b}$ shows the PAni-AMPS thermogram, which exhibited two main characteristics of weight transitions, like classical doped polyaniline [72]. First, the two thermal degradation steps from $160-360{ }^{\circ} \mathrm{C}$ and $360-625{ }^{\circ} \mathrm{C}$ were assigned, respectively, to the AMPS anion loss, corresponding to $46 \%$, and the backbone decomposition, corresponding to $43 \%$ [73]. By adjusting these experimental values to $100 \%$, PAni and AMPS anion have a percentage ratio of $48 \%$ and $52 \%$, respectively. Second, in a precise definition, based on the chemical structure of emeraldine salt, the basic unit consists of four aromatic rings at the main chain and two anions, acting as dopants. Thus, the calculated molecular weight of the basic unit of PAni-AMPS is $777.96 \mathrm{~g} \mathrm{~mol}^{-1}$. In addition, the AMPS anion has a molecular weight of $206.24 \mathrm{~g} \mathrm{~mol}^{-1}$, meaning that the dopant accounts for $53 \%$ of the basic unit of PAni-AMPS. Therefore, the percentages obtained experimentally are similar to those calculated, which confirmed the structure of PAni doped with AMPS anion.

Moreover, Ani-AMPS and Poly(Ani-AMPS) showed two transitions close to $210{ }^{\circ} \mathrm{C}$ and $300^{\circ} \mathrm{C}$, assigned to the anilinium cation loss and desulfonation. A third transition close to $425^{\circ} \mathrm{C}$ was also present in Ani-AMPS and Poly(Ani-AMPS), which corresponded to a weight loss of $20 \%$, which was assigned to the decomposition of the amide substituent to form a nitrogen derivative. Finally, Poly(Ani-AMPS), shown in Figure 9c, presented the last transition at $530^{\circ} \mathrm{C}$, ascribed to the thermal decomposition of the polymer backbone [22], corresponding to $19 \%$. As observed, the thermal decompositions of Ani-AMPS and Poly(AniAMPS) have differences in transitions occurring at temperatures above $400{ }^{\circ} \mathrm{C}$. 
To supplement the thermal analysis, Poly(Ani-AMPS) was characterized by differential scanning calorimetry (DSC). Figure 9d shows the thermograms of Poly(Ani-AMPS) and PAMPS-acid (the acid form of Poly(Ani-AMPS)). PAMPS-acid presented a $\mathrm{T}_{\mathrm{g}}$ of $109^{\circ} \mathrm{C}$ according to the literature [22]. Similarly, Poly(Ani-AMPS) presented a $\mathrm{T}_{\mathrm{g}}$ of $110{ }^{\circ} \mathrm{C}$, suggesting that in the solid state, $\pi$-stacking interactions between anilinium cations of Poly(Ani-AMPS) did not affect the polymer chain flexibility.

\subsubsection{Morphology}

Figure 10a,e shows the morphology of Poly(Ani-AMPS) and PAni-AMPS. As observed, the polymers presented entirely different morphologies. Poly(Ani-AMPS) formed a film with some dark domains, ascribed to an increment in the electron density, owing to anilinium ion $\pi$-stacking interactions [74]. These domains showed either vesicle-like (spheres) or lamellar-like (lines) morphology. On the other hand, PAni-AMPS showed fibrillary morphology [75], commonly observed in diluted aniline polymerizations [76]. Likewise, the morphology of polyanilines depends on polymerization methodology [77].

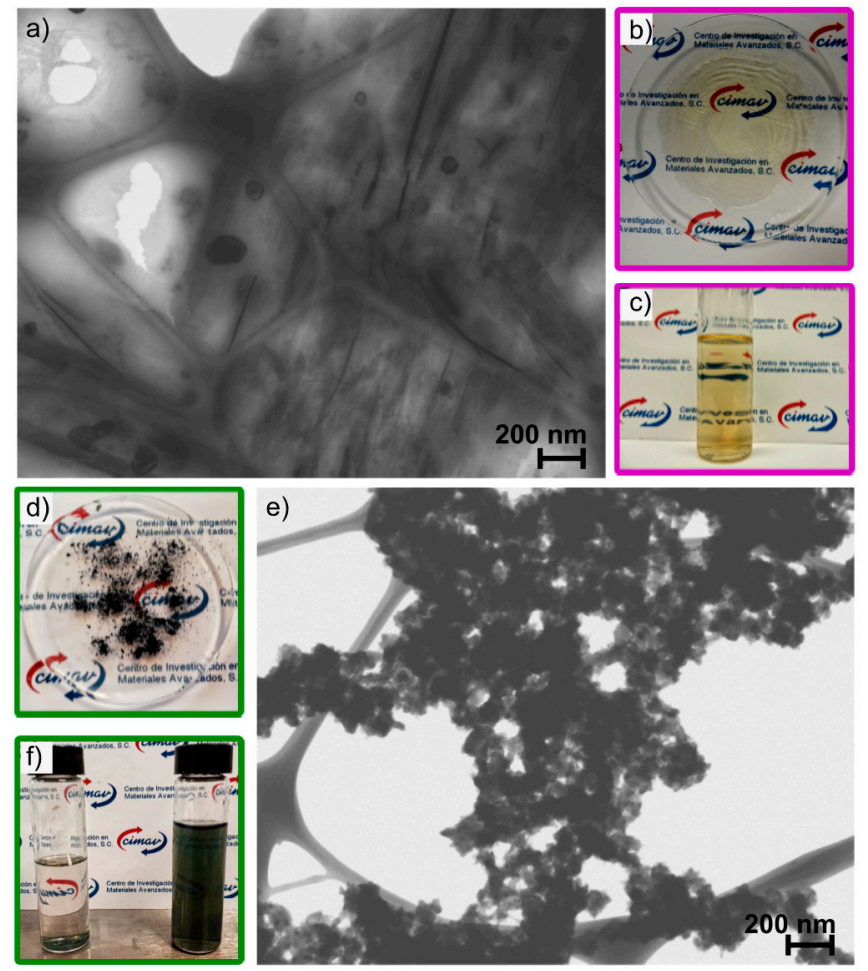

Figure 10. (a) Morphology, (b) solid phase, and (c) water solution of Poly(Ani-AMPS), and (d) solid phase, (e) morphology, and (f) sediment (left) and dispersion (right) in water of PAni-AMPS.

Figure 10b,c show the physical aspect of Poly(Ani-AMPS) in solid-state and aqueous solutions. Furthermore, Poly(Ani-AMPS) was entirely water soluble and formed a yellow translucent film over the substrate. Meanwhile, PAni-AMPS, shown in Figure 10d,f, is a green powder in the solid state, typical of emeraldine salt. The aqueous phase forms an unstable suspension that precipitates after some minutes. The observed differences in both morphology and behavior are a consequence of the characteristic molecular structure of each polymer.

\section{Conclusions}

The design and development of anilinium 2-acrylamide-2-methyl-1-propanesulfonate (Ani-AMPS) monomer allows the synthesis of complex polymeric systems with different attributes to conventional polymers. The Ani-AMPS monomer was submitted to selective polymerization by free-radical polymerization and oxidative polymerization, producing poly(anilinium 2-acrylamide-2-methyl-1-propanesulfonic) [Poly(Ani-AMPS)] and polyani- 
line doped with 2-acrylamide-2-methyl-1-propanesulfonic acid PAni-AMPS, respectively. The position of the anilinium cation as a counterion (Poly(Ani-AMPS)) or as part of the polymer backbone (in PAni-AMPS) played an essential role in the optical properties of each polymer. For Poly(Ani-AMPS), $\pi-\pi^{*}$ transition of aromatic rings favored a $\pi$-stacking conformation by the presence of the 2-acrylamide-2-methylpropane-1-sulfonate that links the polymer main chain with the anilinium cation. The $\pi$-stacking conformation gives the polymer different absorption bands and intensities, depending on the solvent and polymer concentration. Notably, the photoluminescence properties of Poly(Ani-AMPS), water solubility, and the simplicity of the methodology could be employed to develop a fluorescent sensor to identify water-soluble iron ions. Meanwhile, for PAni-AMPS, although having the same $\pi-\pi^{*}$ transitions, the conjugation of the aromatic rings is increased by the polymerization process. The absorption bands in this polymer are related to the presence or absence of the dopant. In this case, dedoping occurred above $\mathrm{pH}$ 4.4. These structural differences were also observed in thermal stability since each polymer presents different thermogravimetric traces. As for the morphology, Poly(Ani-AMPS) produced a translucent film, whereas the PAni-AMPS formed water-insoluble short nanofibers. Additionally, in Poly(Ani-AMPS), the anilinium ion opens the possibility to graft a conducting polymer, by oxidative polymerization, over its surface to design conductive inks.

\section{Patents}

Mx/a/2019/015137 "Process of synthesis of polyfunctional comonomers and their polymerization".

Supplementary Materials: The following are available online at https:/ /www.mdpi.com/article/ 10.3390 / polym13142349/s1, Figure S1. ${ }^{1} \mathrm{H}$ NMR $(400 \mathrm{MHz}$, deuterium oxide) $87.64-7.54(\mathrm{~m}, 3 \mathrm{H})$, $7.45(\mathrm{dt}, J=8.0,1.5 \mathrm{~Hz}, 2 \mathrm{H}), 6.26(\mathrm{dd}, J=17.1,10.1 \mathrm{~Hz}, 1 \mathrm{H}), 6.16(\mathrm{dd}, J=17.1,1.5 \mathrm{~Hz}, 1 \mathrm{H})$, $5.72(\mathrm{dd}, J=10.1,1.5 \mathrm{~Hz}, 1 \mathrm{H}), 3.44(\mathrm{~s}, 2 \mathrm{H}), 1.53(\mathrm{~s}, 6 \mathrm{H}) ;{ }^{13} \mathrm{C}$ NMR $(101 \mathrm{MHz}$, deuterium oxide) $\delta$ 197.79, 130.99, 130.11, 129.75, 129.20, 126.57, 122.85, 57.15, 51.98, 26.36 ppm. Figure S2. ${ }^{1} \mathrm{H}$ NMR $(400 \mathrm{MHz}$, deuterium oxide) $\delta 7.80-7.29(\mathrm{~m}, 10 \mathrm{H}), 3.71(\mathrm{t}, J=6.3 \mathrm{~Hz}, 1 \mathrm{H})$, $3.49-3.25(\mathrm{~m}, 4 \mathrm{H}), 2.67(\mathrm{t}, J=6.3 \mathrm{~Hz}, 1 \mathrm{H}), 2.10(\mathrm{~m}, 2 \mathrm{H}), 1.82-1.55(\mathrm{~m}, 2 \mathrm{H}), 1.53-1.43(\mathrm{~m}, 12 \mathrm{H})$; ${ }^{13} \mathrm{NMR}(101 \mathrm{MHz}$, deuterium oxide) $\delta 170.89,167.79,133.93,130.98,130.43,130.14,129.65,129.67$, $126.56,122.94,122.69,57.12,56.59,51.97,51.87,47.73,31.30,26.55,26.37,26.35$ ppm. Table S1. Fluorescence intensity values concerning concentration of $\mathrm{Fe}^{2+}$. Table S2. Fluorescence intensity values concerning concentration of $\mathrm{Fe}^{3+}$.

Author Contributions: Conceptualization, E.A.Z.-C. and A.V.-R.; methodology, A.S.C.-D., M.A.M.-Q. and A.V.-R.; investigation NMR, D.C.-F.; investigation, A.S.C.-D., M.A.M.-Q. and A.V.-R.; validation, A.S.C.-D., M.A.M.-Q., D.C.-F. and A.V.-R.; writing-original draft preparation, A.S.C.-D., M.A.M.-Q. and D.C.-F.; writing—review and editing, A.V.-R. and E.A.Z.-C.; project administration, A.V.-R. and E.A.Z.-C.; supervision, E.A.Z.-C.; funding acquisition, E.A.Z.-C. All authors have read and agreed to the published version of the manuscript.

Funding: This project was financed by the National Council for Science and Technology of Mexico (CONACYT), grant number CB2016-288802-Q.

Institutional Review Board Statement: Not applicable.

Informed Consent Statement: Not applicable.

Data Availability Statement: Not applicable.

Acknowledgments: We wish to thank CONACYT for the scholarship awarded to Alain ConejoDávila (627922). We also wish to thank Claudia Hernández, Daniel Lardizabal, Karla Campos, and Luis de la Torre for their valuable support during the development of this research.

Conflicts of Interest: The authors declare no conflict of interest. 


\section{References}

1. Gerrits, L.; Hammink, R.; Kouwer, P.H.J. Semiflexible polymer scaffolds: An overview of conjugation strategies. Polym. Chem. 2021, 12, 1362-1392. [CrossRef]

2. Plummer, C.M.; Li, L.; Chen, Y. The post-modification of polyolefins with emerging synthetic methods. Polym. Chem. 2020, 11, 6862-6872. [CrossRef]

3. Brännström, S.; Johansson, M.; Malmström, E. Enzymatically Synthesized Vinyl Ether-Disulfide Monomer Enabling an Orthogonal Combination of Free Radical and Cationic Chemistry toward Sustainable Functional Networks. Biomacromolecules 2019, 20, 1308-1316. [CrossRef]

4. Liu, H.; Dong, X.; Liu, F.; Zheng, J.; Sun, Y. Iminodiacetic acid-conjugated nanoparticles as a bifunctional modulator against Zn2+-mediated amyloid $\beta$-protein aggregation and cytotoxicity. J. Colloid Interface Sci. 2017, 505, 973-982. [CrossRef] [PubMed]

5. Zhang, W.; Yang, L.; Zhang, H.; Lin, W.; Wang, Y. Investigation on multifunctional monomer modified polypropylene and its foamability. J. Appl. Polym. Sci. 2013, 130, 1675-1681. [CrossRef]

6. Sivanesan, D.; Seo, B.K.; Lim, C.S.; Kim, S.; Kim, H.G. Trifunctional cycloaliphatic epoxy-based thermoset polymers: Synthesis, polymerization, and characterization. Polymer 2021, 220. [CrossRef]

7. Chan, E.W.; Baek, P.; Barker, D.; Travas-Sejdic, J. Highly functionalisable polythiophene phenylenes. Polym. Chem. 2015, 6, 7618. [CrossRef]

8. $\quad$ Klein, R.; Übel, F.; Frey, H. Maleimide Glycidyl Ether: A Bifunctional Monomer for Orthogonal Cationic and Radical Polymerizations. Macromol. Rapid Commun. 2015, 36, 1822-1828. [CrossRef] [PubMed]

9. Conejo-Dávila, A.S.; Hernández-Escobar, C.A.; Vega-Rios, A.; Rodríguez-Sánchez, I.; Estrada-Monje, A.; de León-Gómez, R.E.; Zaragoza-Contreras, E.A. Selective polymerization of a new bifunctional monomer via free radical polymerization and oxidative route. Synth. Met. 2020, 259, 116258. [CrossRef]

10. Usha, R.; Hema, N.; Ambika, V.R.; Shalini, D.; Jayalakshmi, D. Synthesis, growth and characterization of nonlinear optical organic crystal: 4-Methoxy Anilinium 5-Sulfo Salicylate. Mater. Res. Innov. 2019, 23, 107-112. [CrossRef]

11. Cruz-Medina, R.; Vega-Rios, A.; Hernández-Escobar, C.A.; Estrada-Monje, A.; Rodríguez-Sánchez, I.; Zaragoza-Contreras, E.A. Polystyrene-polyaniline core-shell composite particles using a bifunctional selectively polymerizable monomer as the interfacial linkage. Synth. Met. 2020, 265, 116402. [CrossRef]

12. Martinez, C.R.; Iverson, B.L. Rethinking the term "pi-stacking". Chem. Sci. 2012, 3, 2191-2201. [CrossRef]

13. Marchewka, M.K.; Pietraszko, A. Structural and vibrational studies of anilinium nitrate. J. Phys. Chem. Solids. 2005, 66, 1039-1048. [CrossRef]

14. Vivek, P.; Jauhar, R.M.; Suvitha, A.; Era, P.; Ananth, S.; Murugakoothan, P. Habitual growth and its influence on the properties of anilinium perchlorate (AP) single crystal for nonlinear optical device applications. J. Mater. Sci. Mater. Electron. 2018, 29, 5718-5725. [CrossRef]

15. Sudharsana, N.; Subramanian, G.; Krishnakumar, V.; Nagalakshmi, R. Growth and characterization of anilinium hydrogen sulfate (AHS) single crystals: An organic nonlinear optical material. Spectrochim. Acta Part A Mol. Biomol. Spectrosc. 2012, 97, 798-805. [CrossRef] [PubMed]

16. Zaragoza-Contreras, E.A.; Stockton-Leal, M.; Hernández-Escobar, C.A.; Hoshina, Y.; Guzmán-Lozano, J.F.; Kobayashi, T. Synthesis of core-shell composites using an inverse surfmer. J. Colloid Interface Sci. 2012, 377, 231-236. [CrossRef] [PubMed]

17. Zou, F.; Yu, X.; Zhang, J.; Cheng, N.; Huang, X. Electropolymerization in a novel proton functionalized room temperature ionic liquid anilinium acetate. Synth. Met. 2015, 204, 76-83. [CrossRef]

18. Kobayashi, Y.; Sumi, S.; Terauchi, T.; Hashizume, D. Ionic semiconductor: DC and AC conductivity of anilinium tetrathiafulvalene2-carboxylate. Dalt. Trans. 2013, 42, 3821-3826. [CrossRef] [PubMed]

19. Yoshii, Y.; Hoshino, N.; Takeda, T.; Moritomo, H.; Kawamata, J.; Nakamura, T.; Akutagawa, T. The Formation of Organogels and Helical Nanofibers from Simple Organic Salts. Chem. A Eur. J. 2014, 20, 16279-16285. [CrossRef]

20. Du, X.-S.; Zhou, C.-F.; Wang, G.-T.; Mai, Y.-W. Novel Solid-State and Template-Free Synthesis of Branched Polyaniline Nanofibers. Chem. Mater. 2008, 20, 3806-3808. [CrossRef]

21. Raghava, K.; Pill, K.; Iyengar, A. Self-assembly approach for the synthesis of electro-magnetic functionalized $\mathrm{Fe}_{3} \mathrm{O}_{4} / \mathrm{polyaniline}$ nanocomposites: Effect of dopant on the properties. Colloids Surfaces A Physicochem. Eng. Asp. 2008, 320, 49-56. [CrossRef]

22. Tutgun, M.S.; Sinirlioglu, D.; Celik, S.U.; Bozkurt, A. Preparation and characterization of hexagonal boron nitride and PAMPSNMPA-based thin composite films and investigation of their membrane properties. Ionics 2015, 21, 2871-2878. [CrossRef]

23. Wang, J.; Yu, X.; Wang, C.; Xiang, K.; Deng, M.; Yin, H. PAMPS/MMT composite hydrogel electrolyte for solid-state supercapacitors. J. Alloys Compd. 2017, 709, 596-601. [CrossRef]

24. Pehlivan, L.; Métay, E.; Laval, S.; Dayoub, W.; Demonchaux, P.; Mignani, G.; Lemaire, M. Alternative method for the reduction of aromatic nitro to amine using TMDS-iron catalyst system. Tetrahedron Lett. 2011, 67, 1971-1976. [CrossRef]

25. Aguilar, R.; Gallardo, A.; Ferna, M. In Situ Quantitative 1 H NMR Monitoring of Monomer Consumption: A Simple and Fast Way of Estimating Reactivity Ratios. Macromolecules 2002, 35, 2036-2041. [CrossRef]

26. Nadim, E.; Bouhendi, H.; Ziaee, F.; Nouri, A. Kinetic Study of the Aqueous Free-Radical Polymerization of 2-Acrylamido-2Methyl-1-Propanesulfonic Acid via an Online Proton Nuclear Magnetic Resonance Technique. J. Appl. Polym. Sci. 2012, 126, 156-161. [CrossRef] 
27. Evans, J.C. The vibrational assignments and configuration of aniline, aniline-NHD and aniline-ND2. Spectrochim. Acta. 1960, 16, 428-442. [CrossRef]

28. Das, M.; Devi, N.; Sarma, J.; Devi, N. Preparation, characterization, and water sorption study of 2-acrylamido-2- methylpropane sulfonic acid ( AMPS ) based hydrogel. J. Chem. Pharm. Res. 2014, 6, 800-806.

29. Kim, S.K.; Lim, J.M.; Pradhan, T.; Jung, H.S.; Lynch, V.M.; Kim, J.S.; Kim, D.; Sessler, J.L. Self-Association and NitroaromaticInduced Deaggregation of Pyrene Substituted Pyridine Amides. J. Am. Chem. Soc. 2014, 136, 495-505. [CrossRef]

30. Morisaki, Y.; Ishida, T.; Chujo, Y. Synthesis and Optical Properties of Novel Through-Space $\pi$-Conjugated Polymers Having a Dithia[3.3]metacyclophane Skeleton in the Main Chain. Polym. J. 2003, 35, 501-506. [CrossRef]

31. Ovchinnikov, O.V.; Evtukhova, A.V.; Kondratenko, T.S.; Smirnov, M.S.; Khokhlov, V.Y.; Erina, O.V. Manifestation of intermolecular interactions in FTIR spectra of methylene blue molecules. Vib. Spectrosc. 2016, 86, 181-189. [CrossRef]

32. Shen, Y.; Xi, J.; Qiu, X.; Zhu, W. A new proton conducting membrane based on copolymer of methyl methacrylate and 2-acrylamido-2-methyl-1-propanesulfonic acid for direct methanol fuel cells. Electrochim. Acta. 2007, 52, 6956-6961. [CrossRef]

33. Dai, J.; Coh, S.H.; Lee, S.Y.; Slow, K.S. Complexation between poly(2-hydroxypropyl methacrylate) and three tertiary amide polymers. J. Appl. Polym. Sci. 1994, 54, 1585. [CrossRef]

34. Sun, J.; Shang, K.; Wu, Y.; Zhang, Q.; Yao, X.; Yang, Y.; Hu, D.; Liu, J. Three new Coordination Polymers based on a 1-(3,5-dicarboxy-benzyl)-1H-pyrazole-3,5-dicarboxylic acid ligand: Synthesis, crystal structures, magnetic properties and selectively sensing properties. Polyhedron 2018, 141, 223-229. [CrossRef]

35. Joshi, J.C.; Pant, D.D. Characteristic luminescence of the anilinium ion and the pKa values of excited singlet and triplet states. Chem. Phys. Lett. 1978, 59, 529-532. [CrossRef]

36. Zhang, X.; Chen, Y.; Cai, X.; Caiyun, L.; Jia, P.; Li, Z.; Zhu, H.; Yu, Y.; Wang, K.; Li, X.; et al. A highly sensitive rapid-response fluorescent probe for specifically tracking endogenous labile Fe2+ in living cells and zebrafish. Dye. Pigment. 2020, 174, 108065 [CrossRef]

37. Chen, K.; Liu, Y.; Hu, Y.; Yuan, M.; Zheng, X.; Huang, X. Facile synthesis of amino-functionalized polyphosphazene microspheres and their application for highly sensitive fluorescence detection of $\mathrm{Fe}^{3+}$. J. Appl. Polym. Sci. 2020, 137, 48937. [CrossRef]

38. Selvaraj, M.; Rajalakshmi, K.; Nam, Y.-S.; Lee, Y.; Song, J.-W.; Lee, H.-J.; Lee, K.-B. On-off-on relay fluorescence recognition of ferric and fluoride ions based on indicator displacement in living cells. Anal. Chim. Acta 2019, 1066, 112-120. [CrossRef] [PubMed]

39. Cao, H.; Li, B.; Jiang, X.; Zhu, X.; Zheng, X. Fluorescent linear polyurea based on toluene diisocyanate: Easy preparation, broad emission and potential applications. Chem. Eng. J. 2020, 399, 125867. [CrossRef] [PubMed]

40. Spiliopoulos, I.K. Optical and electrochemical properties and sensing application for iron (II) and mercury (II) ions of polyfluorenes with imidazole in the main chain. Polym. Int. 2019, 68, 1033-1041. [CrossRef]

41. Fu, S.; Cai, Z.; Liu, L.; Yang, L.; Jin, R.; Lu, Z.; Ai, H. Controlled aggregation of amphiphilic aggregation-induced emission polycation and superparamagnetic iron oxide nanoparticles as fluorescence/magnetic resonance imaging probes. J. Appl. Polym. Sci. 2020, 137, 48760. [CrossRef]

42. Tang, T.; Guo, W.; Xu, Y.; Xu, D. Synthesis and characterization of novel hyperbranched fluorescent polymers that can be precisely used for metal ion detection and quantification. J. Appl. Polym. Sci. 2020, 137, 48933. [CrossRef]

43. Yang, C.B.; Jiang, C.B.; Zhang, M.Y.; Chen, X.; Zou, P.; Yang, R.W.; Rao, H.B.; Wang, G.T. A multifunctional Eu-based coordination polymer luminescent sensor for highly sensitive and selective detection of $\mathrm{Fe}^{3+}$ and acetone. Polyhedron 2020, 175, 1-7. [CrossRef]

44. Sendenkova, I.; Trchová, M.; Blinova, N.V.; Stejskal, J. In-situ polymerized polyaniline films. Preparation in solutions of hydrochloric, sulfuric, or phosphoric acid. Thin Solid Films 2006, 515, 1640-1646. [CrossRef]

45. Belaabed, B.; Lamouri, S.; Naar, N.; Bourson, P.; Hamady, S.O.S. Polyaniline-doped benzene sulfonic acid/epoxy resin composites: Structural, morphological, thermal and dielectric behaviors. Polym. J. 2010, 42, 546-554. [CrossRef]

46. Arasi, A.Y.; Jeyakumari, J.J.L.; Sundaresan, B.; Dhanalakshmi, V.; Anbarasan, R. The structural properties of Poly(aniline)-Analysis via FTIR spectroscopy. Spectrochim. Acta Part A Mol. Biomol. Spectrosc. 2009, 74, 1229-1234. [CrossRef] [PubMed]

47. Lin, D.S.; Chou, C.T.; Chen, Y.W.; Kuo, K.T.; Yang, S.M. Electrochemical behaviors of polyaniline-poly(styrene-sulfonic acid) complexes and related films. J. Appl. Polym. Sci. 2006, 100, 4023-4044. [CrossRef]

48. Hechavarría, L.; Hu, H.; Rincón, M.E. Polyaniline-poly(2-acrylamido-2-methyl-1-propanosulfonic acid) composite thin films: Structure and properties. Thin Solid Films 2003, 441, 56-62. [CrossRef]

49. Tawde, S.; Mukesh, D.; Yakhmi, J.V. Redox behavior of polyaniline as in ${ }^{-}$uenced by aromatic sulphonate anions: Cyclic voltammetry and molecular modeling. Synth. Met. 2002, 125, 401-413. [CrossRef]

50. Vivier, V.; Cachet-vivier, C.; Michel, D.; Nedelec, J.; Yu, L.T. Voltamperommetric study of chemically made polyaniline powder with cavity microelectrode technique. Synth. Met. 2002, 126, 253-262. [CrossRef]

51. Shao, L.; Qiu, J.; Liu, M.; Feng, H.; Lei, L.; Zhang, G.; Zhao, Y.; Gao, C.; Qin, L. Synthesis and characterization of water-soluble polyaniline films. Synth. Met. 2011, 161, 806-811. [CrossRef]

52. Pruneanu, S.; Veress, E.; Marian, I.; Oniciu, L. Characterization of polyaniline by cyclic voltammetry and UV-Vis absorption spectroscopy. J. Mater. Sci. 1999, 4, 2733-2739. [CrossRef]

53. Snook, G.A.; Kao, P.; Best, A.S. Conducting-polymer-based supercapacitor devices and electrodes. J. Power Sources 2011, $196,1-12$. [CrossRef]

54. Liu, T.; Finn, L.; Yu, M.; Wang, H.; Zhai, T.; Lu, X.; Tong, Y.; Li, Y. Polyaniline and Polypyrrole Pseudocapacitor Electrodes with Excellent Cycling Stability. Nano Lett. 2014, 14, 2522-2527. [CrossRef] 
55. Kuswandi, B.; Restyana, A.; Abdullah, A.; Heng, L.Y.; Ahmad, M. A novel colorimetric food package label for fish spoilage based on polyaniline film. Food Control. 2012, 25, 184-189. [CrossRef]

56. Li, M.; Guo, Y.; Wei, Y.; MacDiarmid, A.G.; Lelkes, P.I. Electrospinning polyaniline-contained gelatin nanofibers for tissue engineering applications. Biomaterials 2006, 27, 2705-2715. [CrossRef]

57. Chi, K.; Zhang, Z.; Xi, J.; Huang, Y.; Xiao, F.; Wang, S.; Liu, Y. Freestanding Graphene Paper Supported Three-Dimensional Porous Graphene-Polyaniline Nanocomposite Synthesized by Inkjet Printing and in Flexible All-Solid-State Supercapacitor. Appl. Mater. Interfaces. 2014, 6, 16312-16319. [CrossRef]

58. Thompson, J.O.F.; Saalbach, L.; Crane, S.W.; Paterson, M.J.; Townsend, D. Ultraviolet relaxation dynamics of aniline, $\mathrm{N}, \mathrm{N}$-dimethylaniline and 3,5-dimethylaniline at $250 \mathrm{~nm}$. J. Chem. Phys. 2015, 142. [CrossRef]

59. Gospodinova, N.; Mokreva, P.; Terlemezyan, L. Chemical oxidative polymerization of aniline in aqueous medium without added acids. Polymer 1993, 34, 2438-2439. [CrossRef]

60. Kumar, D.; Iwamoto, M. Investigation of the chiroptical behavior of optically active polyaniline synthesized from naturally occurring amino acids. Polym. J. 2013, 45, 160-165. [CrossRef]

61. Boeva, Z.A.; Sergeyev, V.G. Polyaniline: Synthesis, properties, and application. Polym. Sci. Ser. C 2014, 56, 144-153. [CrossRef]

62. Devi, J.S.A.; Aparna, R.S.; Anjana, R.R.; Nebu, J.; Anju, S.M.; George, S. Solvent Effects: A Signature of J- and H-Aggregate of Carbon Nanodots in Polar Solvents. J. Phys. Chem. A. 2019, 123, 7420-7429. [CrossRef] [PubMed]

63. So, Y.; Zaleski, J.M.; Murlick, C.; Ellaboudy, A. Synthesis and Photophysical Properties of Some Benzoxazole and Benzothiazole Compounds. Macromolecules 1996, 29, 2783-2795. [CrossRef]

64. Shibahara, M.; Watanabe, M.; Iwanaga, T.; Matsumoto, T.; Ideta, K.; Shinmyozu, T. Synthesis, structure, and transannular $\pi-\pi$ interaction of three- and four-layered [3.3]paracyclophanes. J. Org. Chem. 2008, 73, 4433-4442. [CrossRef] [PubMed]

65. Wojtyk, J.; McKerrow, A.; Kazmaier, P.; Buncel, E. Quantitative investigations of the aggregation behaviour of hydrophobic anilino squaraine dyes through UV/vis spectroscopy and dynamic light scattering. Can. J. Chem. 1999, 77, 903-912. [CrossRef]

66. Hu, R.; Zhu, Q.; Chen, W.; Liu, H.; Yao, B.; Zhan, J.; Hao, J.; Han, C.C. Ordered dichloro-biphenylene-bridged silsesquioxanes fabricated by interfacial polymerization. Polymer 2012, 53, 267-271. [CrossRef]

67. Griffiths, T.R.; Pugh, D.C. Correlations among solvent polarity scales, dielectric constant and dipole moment, and a means to reliable predictions of polarity scale values from current data. Coord. Chem. Rev. 1979, 29, 129-211. [CrossRef]

68. Petr, A.; Wei, D.; Kvarnström, C.; Ivaska, A.; Dunsch, L. $\pi$-Dimer of an Aniline Dimer: An ESR-UV-Vis Spectroelectrochemical Study. J. Phys. Chem. B 2007, 111, 12395-12398. [CrossRef]

69. Celebioglu, A.; Durgun, E.; Uyar, T. Selective and Efficient Removal of Volatile Organic Compounds by Channel-type GammaCyclodextrin Assembly through Inclusion Complexation. Ind. Eng. Chem. Res. 2017, 56, 7345-7354. [CrossRef]

70. Gong, C.; Pinatti, L.; Lavigne, G.; Shaw, M.T.; Scola, D.A. Thermal stability of end-capped and linear sulfonated polyimides, sulfonated polystyrene, and Nafion 117. J. Appl. Polym. Sci. 2018, 135, 45694. [CrossRef]

71. Pal, S.; Mondal, R.; Guha, S.; Chatterjee, U.; Jewrajka, S.K. Homogeneous phase crosslinked poly(acrylonitrile-co-2-acrylamido-2methyl-1-propanesulfonic acid) conetwork cation exchange membranes showing high electrochemical properties and electrodialysis performance. Polymer 2019, 180, 121680. [CrossRef]

72. Chan, H.S.O.; Teo, M.Y.B.; Khor, E.; Lim, C.N. Thermal analysis of conducting polymers part I. J. Therm. Anal. 1989, 35, 765-774. [CrossRef]

73. Amano, K.; Ishikawa, H.; Kobayashi, A.; Satoh, M.; Hasegawa, E. Thermal stability of chemically synthesized polyaniline. Synth. Met. 1994, 62, 229-232. [CrossRef]

74. Gong, X.; Li, G.; Wu, Y.; Zhang, J.; Feng, S.; Liu, Y.; Li, C.; Ma, W.; Bo, Z. Enhancing the Performance of Polymer Solar Cells by Using Donor Polymers Carrying Discretely Distributed Side Chains. ACS Appl. Mater. Interfaces. 2017, 9, 24020-24026. [CrossRef]

75. Fang, F.F.; Dong, Y.-Z.; Choi, H.J. Effect of oxidants on morphology of interfacial polymerized polyaniline nanofibers and their electrorheological response. Polymer 2018, 158, 176-182. [CrossRef]

76. Abdolahi, A.; Hamzah, E.; Ibrahim, Z.; Hashim, S. Synthesis of uniform polyaniline nanofibers through interfacial polymerization. Materials 2012, 5, 1487-1494. [CrossRef]

77. Shishov, M.A.; Moshnikov, V.A.; Sapurina, I.Y. Nanostructures of oligoaniline and polyaniline and their properties. Glas. Phys. Chem. 2011, 37, 106-110. [CrossRef] 